\title{
BALANCE SHEET VULNERABILITY AND MACROECONOMIC MANAGEMENT IN INDONESIA
}

\author{
MirandaS. Goeltom
}

The economic and financial crises hitting Indonesia in 1997 have triggered a significanteconomic downturn. A critical issue addressed is how common shocks during crisis period have brought about macroeconomic outcome. The paper briefly discusses the problems, response and lessons learnt in the country's effort to restore the economy to its long-term potential growth path. By examining balance sheet conditions across sectors in the economy, it is shown that even though some progress has been achieved, overall balance sheet conditions are still vulnerable to further shocks that may hit the economy, so that efforts to restore economic growth and stability face substantial challenges. Considering these constraints, Indonesian macroeconomic policy makers focus their efforts on strengthening financial markets, among others, by developing bond markets and implementing banking architecture. However, various constraints will remain unless the government speeds up the necessary reforms, mostly institutional in nature.

Keywords: adjustment and reform program; balance sheet vulnerability; economic crises (1997); Indonesia flow of funds; macroeconomic management 
Gadjah Mada International Journal of Business, May-August 2005, Vol. 7, No. 2

\section{Introduction}

The economic and financial crises hitting Indonesia since mid-1997 had triggered a significant economic downturn, especially in the banking system, business sector, and social and political environment. Mounting inflationary pressure along with battered rupiah exchange rate further compounded the deterioration of the economic fundamentals. A vicious depreciation-inflation spiral following the excessive expansion of money supply due to the bank run precipitated the threat of hyperinflation. With confidence in the banking system eroded, the financial intermediary function of banks virtually came to a halt, resulting in a sharp fall in production and investment. It ended up with a deep contraction of the entire economy, accompanied by heightened social and political tensions emanating from massive unemployment and widespread poverty.

To address the crisis, the government pursued a number of policy measures on both demand and supply sides. On the demand side, the policy focused on alleviating the negative impact of the crisis on the poor by introducing a Social Safety Net Program, followed by measures to revitalize investment and trade activities. On the supply side, policies focused on structural adjustments in order to rehabilitate the banking and business sectors. Meanwhile, efforts to contain inflationary pressures proceeded with monetary tightening and the easing of sup- ply-side shortages through the extension of program credit and the rehabilitation of distribution chains.

The rest of the paper will briefly discuss the problems, responses and lessons learnt in the Indonesia's effort to restore the economy to its long-term potential growth path, organized as follows. Section 2 explores the balance sheet conditions during the crisis and the beginning of economic recovery. Section 3 traces the macro stability adjustment programs conducted by the Government and Bank Indonesia, with the support of the International Monetary Fund and the World Bank. Before the concluding remarks, section 4 discusses the implication of asset market dynamics and balance sheet vulnerability on the current macroeconomic management.

\section{The Financial Crisis and Balance Sheet Conditions}

Before the crisis, i.e., in 1996 and early 1997, Indonesia's macroeconomic indicators were strong. There was a budget surplus, a modest -and seemingly financeable- current account deficit, ongoing economic growth and reasonable price, monetary and exchange rate stability. The Thailand's currency crisis triggered the crisis in Indonesia. Contagion seems to have been the main instigating force for the crisis. The situation was made worsen by the underlying weaknesses and difficulties of Indonesia's economy, many of which had been neglected during the previ- 
ous booming times. Most importantly, there had been a build-up of unhedged short-term borrowings in foreign currency by banks and corporates in the months preceding the crisis. Unfortunately, this build-up was not adequately reflected in the data available at the time.

All this not withstanding, the effects of the crisis on the Indonesian real economy have been devastating. Table 1 provides a summary of some of these effects, e.g., the decline in GDP, the drop in investment, the turnaround in the balance of payments and the implicit transfer of resources from Indonesia abroad, the increase in inflation, etc. Strains on the monetary econo-my and financial system were also not adequately reflected in the aggregate numerical data. Pressures on the exchange rate and reserves early in the crisis forced the monetary authorities to abandon the defense of the exchange rate and let the rupiah float. As a consequence, in such an open capital economy, this shift in policy was accompanied by enormous exchange rate volatility and overshooting.

There were other important effects of the crisis that were not adequately reflected in Table 1 , such as a sudden fall in consumption levels, a deterioration in living standard, and thus the concomitant increase in poverty. In this regard, the financial crisis has reversed Indonesia's track record of steady poverty reduction for decades. According to the best available estimates, poverty rate ${ }^{1}$ increased dramatically, from 11.3 percent in 1996 to 23.6 percent in 1999. The crisis hit urban areas more severely. However, because of the linkages between urban and rural areas, the repercussions of the crisis were felt widely and resulted in a steep rise in poverty in rural areas and of Java as well. The Gini index increased from 34.0 in 1993 to 36.0 in 1996 but then decreased from 1998 to 1999 (Circle-Indonesia, 2002).

The crisis also exhibited a destabilizing dynamic, which in itself constituted a vicious cycle. The loss of confidence early in the crisis led to bank runs. To prevent the collapse of the banking system, Bank Indonesia was obliged, as the lender of last resort, to provide large-scale liquidity support facilities to troubled banks, temporarily losing monetary control in early 1998. Stock of money soared, pushed up prices, and further weakened confidence. The increased money stock, coupled with the loss of confidence, led to further currency depreciation, which in turn eroded confidence, etc. A major victim of this cycle was the Indonesian banking system, which had largely borrowed and lent in foreign currency. In addition, subsequent events have also revealed weaknesses in the system of prudential regulation and supervision for the banking system.

${ }^{1}$ Incidence of Poverty (Head Count Index), estimated by International Labor Organization (2002). 
Gadjah Mada International Journal of Business, May-August 2005, Vol. 7, No. 2

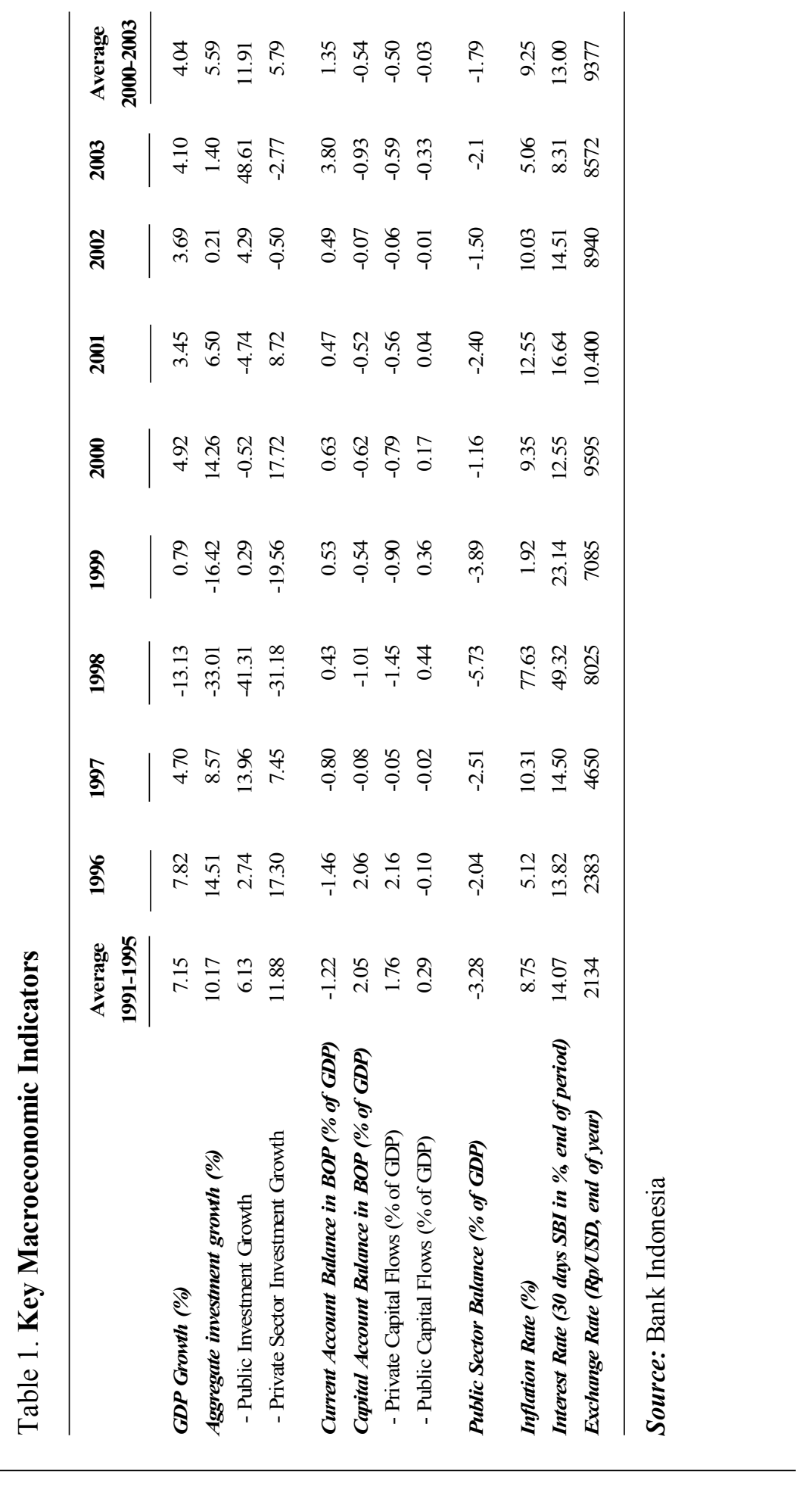


Figure 1. Non Performing Loans

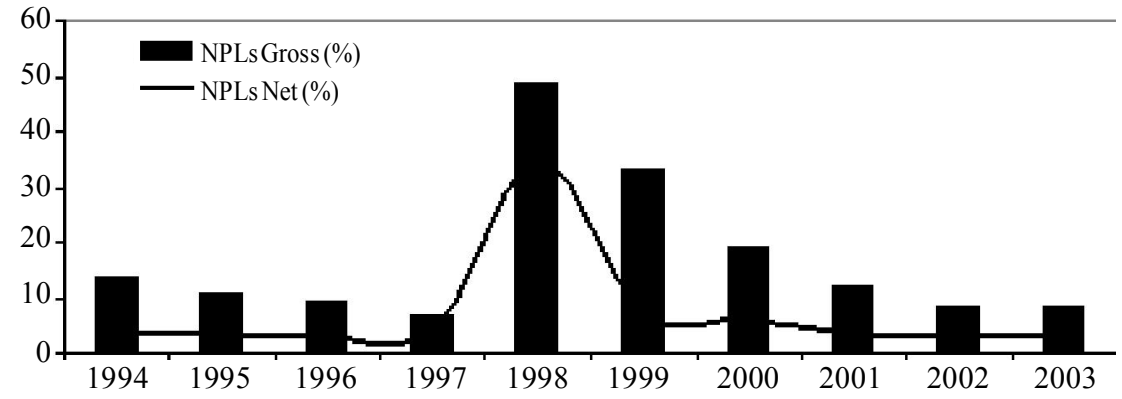

Figure 2. Capital Adequacy Ratio

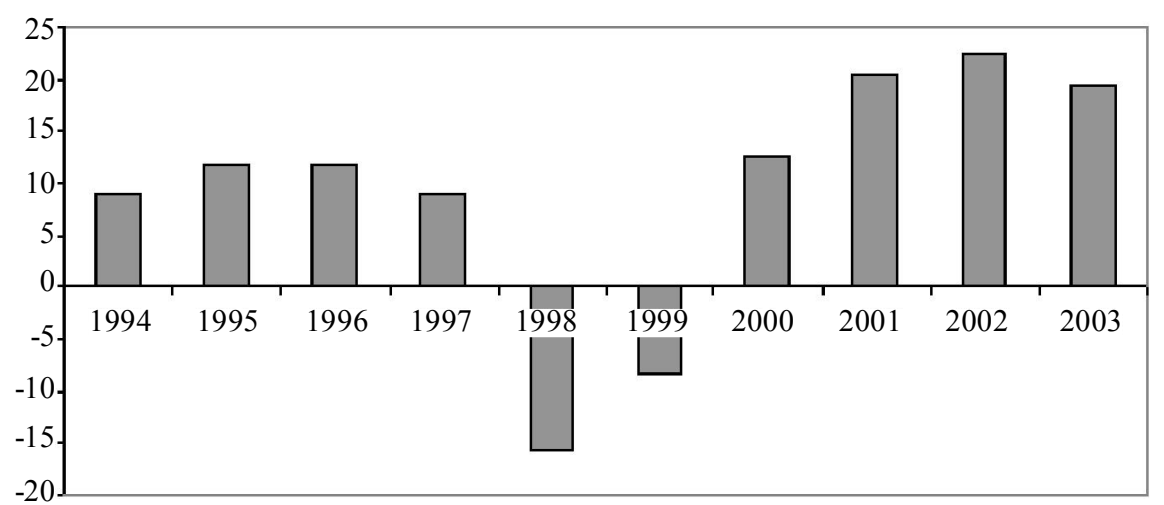

Source: Bank Indonesia

Suddenly banks' borrowers were unable to service their loans, converting effectively what the banks had thought was a currency risk passed on to the borrowers into a credit risk for them. Non-performing loans grew dramatically (Figure 1), and the banking system -or much of it- became technically insolvent (Figure 2).

A relevant question raised here is how the common shocks during the crisis period have brought about macroeconomic outcome? In addressing this issue, we need to examine balance sheet conditions both at economy-wide and sectoral levels, since some sectors of the economy are highly vulnerable to structural shocks. Key characteristics of balance sheet conditions of different sectors and country aggregates in the full sample period during the crisis and staggered economic recovery (19942003) are reviewed in the following section.

\section{The Structure of Financing} Gap: The Overall Picture

Table 2 depicts the structure of percentage of the financing gap to GDP across sectors. Clearly, the economic 
Gadjah Mada International Journal of Business, May-August 2005, Vol. 7, No. 2

crisis has brought about a decline in the role of the government (public) sector from 3.5 percent in 1997 to minus 0.1 percent in 2001 . It was mainly due to the sharp increase in government expenditure to provide the Social Safety Net to the poor which later on were mostly allocated to promote economic growth, and hence to reduce gross public savings. Afterwards, during the economic recovery process, the public sector showed remarkable progress and reached 1.1 percent in 2003.

The corporate sector, both stateowned and private, showed fluctuating developments. The state-owned corporate sector experienced deficits during the period of 1994-2003, except in 1999 where it recorded a surplus of 6.1 percent. It occurred because during 1999, both state and private corporate sectors restrained to invest as the political situation was covered by uncertainties. The private corporate sector experienced slightly larger surpluses in 2001 and 2002. It is worth noting that the net borrowings of the private corporate sector were generally larger than those of state corporate sector, reflecting the limitations faced by the State Corporate Sector to borrow externally because of $\mathrm{PKLN}^{2}$ regulations. Despite some fluctuations, the household sector was the only sector which always experienced surpluses during the period of 1994-
2003. It seems that declining corporate businesses in the net borrowing was substituted by other sector performance, especially household.

It is interesting to observe the fluctuations in the financial sector during the period 1994-2003. As a result of the tight monetary policies introduced in 1998 to absorb huge excess liquidity in order to fight inflationary pressures, banks had to bear high deposit interest rate without capacity to lend the funds, resulting in a huge negative spread. This Credit Crunch depicting the incapacitated banking sector as intermediary agent was the main cause of a structural net borrowing position by the financial sector. Meanwhile, nonbank financial institutions generally contributed less than one percent to GDP.

The steady improvement in overall macro economy and socio-political condition has gradually reversed the picture and recorded the highest momentum in 2001 with a surplus of 2.9 percent of GDP. From Figure 3 it can be seen that while saving and investment steadily increased, the net borrowing (S-I) gap fluctuated during the last decade. This confirms that the recovery process is staggering and is vulnerable to subsequent shocks. The following section explores a broad scope of macroeconomic policies aimed at maintaining stability in the post crisis period.

\footnotetext{
${ }^{2}$ PKLN (Pinjaman Komersial Luar Negeri) or Offshore Commercial Borrowing Regulation was applicable to limit borrowing capacity of the State Corporate Sector.
} 
Goeltom-Balance Sheet Vulnerability and Macroeconomic Management in Indonesia

Table 2. The Structure of Net Borrowing by Sectors to GDP 1994-2003 (\%)

\begin{tabular}{|c|c|c|c|c|c|c|c|c|}
\hline Sector & $\begin{array}{c}\text { Average } \\
94-96\end{array}$ & 1997 & 1998 & 1999 & 2000 & 2001 & 2002 & 2003 \\
\hline A. Non Financial & -3.74 & -8 & 2.69 & 11.72 & (3.64) & 2.07 & 1.56 & (1.16) \\
\hline 1. Government & 1.74 & 3.45 & 0.57 & 0.51 & 0.79 & $(0.11)$ & 0.79 & 1.07 \\
\hline 2. Corporate & -8.88 & -13.67 & -2.8 & 6.09 & $(5.45)$ & $(1.66)$ & $(1.83)$ & $(6.33)$ \\
\hline 2.1. State & -0.91 & -1.23 & -0.43 & 3.03 & $(2.43)$ & $(1.83)$ & $(2.00)$ & $(0.44)$ \\
\hline 2.2. Private & -7.97 & -12.44 & -2.37 & 3.06 & $(3.03)$ & 0.17 & 0.17 & (5.89) \\
\hline 3. Household & 3.40 & 2.22 & 4.92 & 5.12 & 1.03 & 3.84 & 2.60 & 4.10 \\
\hline B. Financial & 0.44 & 7.69 & -2.03 & -10.73 & 4.50 & 0.86 & 0.15 & 4.05 \\
\hline 4. Bank* & 0.28 & 7.97 & -1.49 & -10.42 & 4.50 & 0.93 & 0.07 & 4.05 \\
\hline 5. Non-Bank & 0.16 & -0.28 & -0.53 & -0.31 & 0.01 & $(0.07)$ & 0.09 & $(0.00)$ \\
\hline C. External & & - & - & - & - & - & - & \\
\hline TOTAL & 2.27 & -0.31 & 0.67 & 0.99 & 0.87 & 2.93 & 1.71 & 2.89 \\
\hline GDP (billion Rp) & 456,434 & 627,695 & 955,753 & $1,109,979$ & $1,389,770$ & $1,684,281$ & $1,897,800$ & $2,086,758$ \\
\hline
\end{tabular}

*) includes monetary authority

Source: Central Statistics Board

Figure 3. Net Borrowing of the Economy

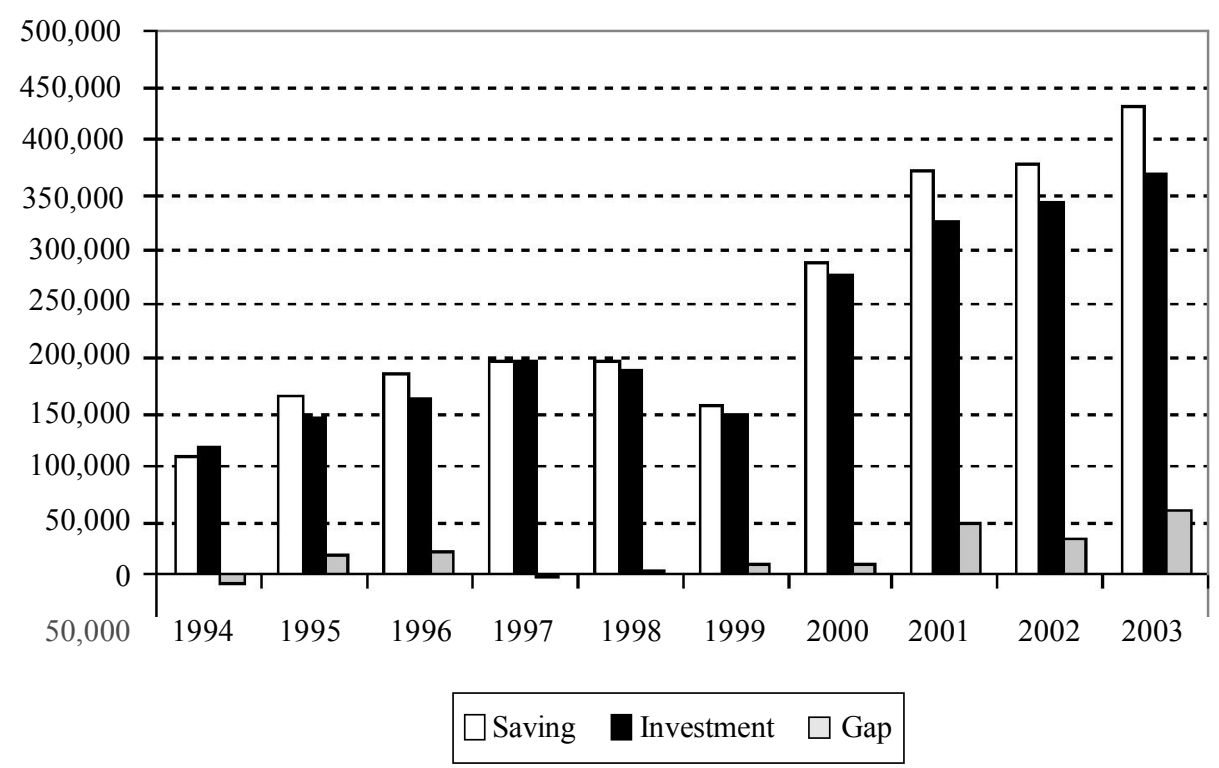

Source: Central Statistics Board 
Gadjah Mada International Journal of Business, May-August 2005, Vol. 7, No. 2

The Structure of Gross Savings and Non-financial Investment

Table 3 shows the developments of gross savings during the period of 1994-2003. It confirms the severity of crisis experienced by the economy, whereby gross saving as a percentage of GDP dropped by more than a half from around 30 percent in period before the crises to 13 percent in 1999. Clearly, the government (public) sector was less volatile, with its largest budget allocated mainly for debt principle repayment and central government spending. Meanwhile, the corpo- rate sector experienced substantial fluctuations, ranging from 24 percent to 95 percent of total gross saving in 1999. In line with the corporate sector developments, the household sector also depicted similar fluctuations, ranging from 15 percent to 56 percent of total gross saving (households). The substantial increase in gross savings in both sectors during the first three years of the crisis (1997 to 1999) was mainly due to the dramatic decline in the financial sector gross saving. Having experienced reversal developments, the corporate and household sectors grew steadily during the economic recovery

Table 3. The Structure of Gross Savings by Sectors 1994-2003 (\%)

\begin{tabular}{|c|c|c|c|c|c|c|c|c|}
\hline Sector & $\begin{array}{c}\text { Average } \\
94-96\end{array}$ & 1997 & 1998 & 1999 & 2000 & 2001 & 2002 & 2003 \\
\hline A. Non Financial & 86.74 & 73.19 & 111.51 & 187.91 & 79.55 & 109.17 & 107.68 & 91.03 \\
\hline 1. Government & 24.74 & 28.06 & 24.33 & 37.01 & 21.54 & 15.98 & 22.33 & 28.31 \\
\hline 2. Corporate & 41.56 & 29.82 & 47.19 & 94.91 & 43.64 & 62.70 & 54.04 & 33.28 \\
\hline 2.1. State & 7.64 & 5.9 & 9.04 & 28.33 & 6.24 & 17.27 & 23.45 & 19.79 \\
\hline 2.2. Private & 33.92 & 23.92 & 38.15 & 66.57 & 37.40 & 45.43 & 30.60 & 13.49 \\
\hline 3. Household & 20.44 & 15.3 & 40 & 55.99 & 14.37 & 30.50 & 31.30 & 29.43 \\
\hline B. Financial & 2.70 & 25.83 & -8.19 & -80.38 & 24.82 & 6.04 & 1.75 & 25.23 \\
\hline 4. Bank* & 2.04 & 26.21 & -5.06 & -78.3 & 24.54 & 6.18 & 1.08 & 24.97 \\
\hline 5. Non-Bank & 0.66 & -0.38 & -3.13 & -2.07 & 0.28 & $(0.14)$ & 0.67 & 0.26 \\
\hline C. External & 10.55 & 0.99 & -3.33 & -7.53 & $(4.37)$ & $(15.21)$ & $(9.42)$ & $(16.26)$ \\
\hline 6. External & 10.55 & 0.99 & -3.33 & -7.53 & $(4.37)$ & (15.21) & $(9.42)$ & (16.26) \\
\hline TOTAL & 100 & 100 & 100 & 100 & 100 & 100 & 100 & 100 \\
\hline \multicolumn{9}{|l|}{ Gross Saving } \\
\hline (billion Rp) & 142,426 & 199,301 & 191,272 & 146,224 & 275,881 & 323,875 & 344,895 & 370,817 \\
\hline$\%$ of GDP & 31.23 & 31.75 & 20.01 & 13.17 & 19.85 & 19.23 & 18.17 & 17.77 \\
\hline
\end{tabular}

*) includes monetary authority

Source: Central Statistic Board, Bank Indonesia, Ministry of Finance 
Goeltom-Balance Sheet Vulnerability and Macroeconomic Management in Indonesia

period in 2001 and 2002. The steady growth of these sectors was mainly due to the strengthening of Asian currencies, especially against the US dollar. This condition has also facilitated government and central bank efforts in maintaining macroeconomic and monetary stability.

Interesting developments were also shown by the banking sector (including monetary authority), which not only experienced some fluctuations, but also contributed significantly to the decline in total gross saving. In 1998 and 1999 it declined drastically to a negative saving level, which was mainly caused by ongoing banking recapitalization process. During the same period, non-banking financial sector also experienced the same situation. This development was a logical consequence of the weak banking system and the fact that the corporate sector was not well covered for exchange rate risks.

Furthermore, Table 4 shows the developments of non-financial investment structure during 1994-2003, which declined sharply in 1998 and 1999 , and gradually increased to 20 percent of GDP in 2000 and 18 percent of GDP in 2003. Rather surprisingly, unlike the structure of gross saving which experienced substantial fluctuations, non-financial investments remained relatively stable. All sectors

Table 4.TheStructureofNon-financialInvestmentbySectors1994-2003(\%)

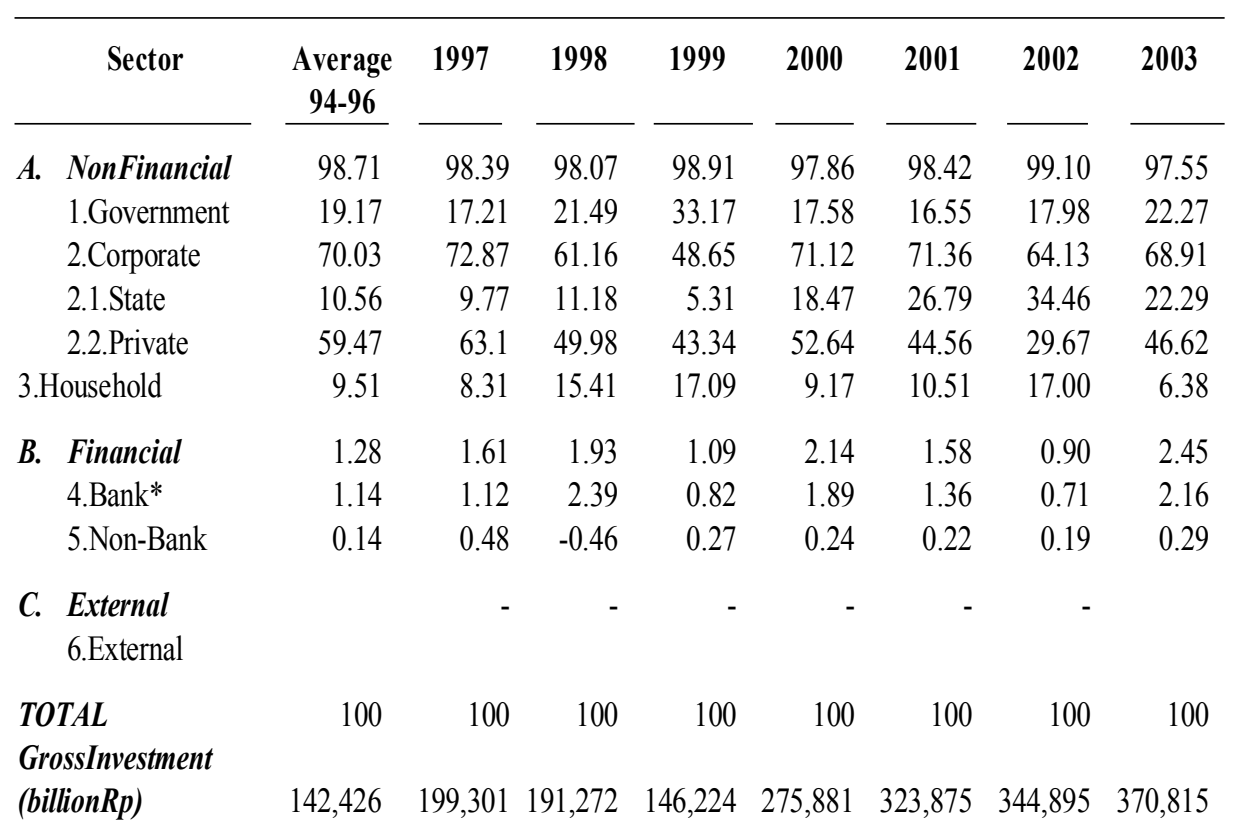

*)includesmonetaryauthority

Source:CentralStatisticBoard,BankIndonesia,MinistryofFinance 
Gadjah Mada International Journal of Business, May-August 2005, Vol. 7, No. 2

(except non-bank in 1998) showed positive investment rates. In 1999, while the corporate and banking sectors investment deteriorated, the government and household sectors showed remarkable developments, with investments reaching the highest rate during the period, above 30 percent and 15 percent of total non-financial investment, respectively.

\section{The Macro Stability Program During Financial Crisis}

To deal with the crisis and unfolding hyperinflation, difficult and tough measures were required. A broad-based policy package included four major elements. First, a primary role was given to a tightening of monetary policies, with a sharp increase in interest rates and strict controls over base money and net domestic assets to achieve macroeconomic stabilization. Second, an adjusted and less restrictive fiscal framework was implemented, with the resulting fiscal deficits in large part financed externally. This expansionary fiscal stance was designed to cover the costs of bank restructuring and recapitalization, the effects of devaluation on external commitments and to provide Social Safety Net measures to cushion the impact of the crisis on the poor. Third, to address the virtual collapse of the financial system, an action program for restructuring the banking system and recapitalizing the banks, including complementary measures to deal with corpo- rate debt, was developed and implemented. Finally, continuity was given to a program of structural adjustment and reform, focusing on measures to increase efficiency and competitiveness.

\section{Indonesian Monetary Policies during the Crisis: Emphasis on Stabilization}

Although Bank Indonesia was obliged to provide liquidity support to banks undergoing bank runs in early 1998, monetary control was quickly reestablished. Restrictive monetary policies were implemented around March 1998, with tight target ceilings on base money resulting in slow monetary growth. At the same time, interest rates rose up to over 70 percent in August. The focus of these policies was mainly aimed at restoring price stability, and indirectly along with other factors to restore stability in the foreign exchange market.

A question is whether these policy actions, along with their results, could have been achieved without considerable freedom given to Bank Indonesia. There were clearly short-term costs in terms of output loss driven by high interest rates. The absence of pressure to ease monetary aggregates has allowed Bank Indonesia to target its policies on price (and exchange rate) stability and succeeded in bringing inflation down within a relatively short period

Using the postulates and analytical tools of modern welfare econom- 
Goeltom-Balance Sheet Vulnerability and Macroeconomic Management in Indonesia

ics, a number of economists advanced theoretical arguments that central bank independence increases economic welfare (see Cukierman 1992, and Lippi 1999). Credibility in monetary policy, enhanced by central bank independence, would increase efficiency and provide a nominal anchor in itself. In May 1999 a new Central Bank Law was enacted providing a new legal framework for Indonesia's central bank. Price stability became the single objective of Bank Indonesia, equipped with both 'goal' and 'instrument' independence. ${ }^{3}$ In the new Central Banking Law, the Governor of Bank Indonesia is no longer a member of the Cabinet, although he may participate in meetings of interest. Nor is there any longer a member of the Government (from the Ministry of Finance) on the Board of Governors for Bank Indonesia. Another most important thing is the prohibition of Bank Indonesia under the new legal framework to provide credits or loans to the Government.

While the new law provides considerable scope of independence of action for Bank Indonesia in achieving the stipulated objective, there are also provisions for its accountability. In addition to its accountability in carrying out its functions and meeting its objective, Bank Indonesia is subject to internationally standardized financial controls and auditing. Furthermore, under this new legal framework, Bank
Indonesia is to announce inflation targets as part of its reporting functions. This presumes that Bank Indonesia is able to both forecast inflation and freely aim its policy on reaching inflation targets. Bank Indonesia also has to set guidelines under a loosely termed "Inflation Targeting" framework.

In 2002, three years after the implementation of the Central Bank Law, promising economic developments started to materialize. Although several underlying factors played significant roles, it is believed that the monetary institutional establishment was the main aspect fostering economic stability, not only in the short run, but also in the long-run. During 2003, consistent monetary policies supported by prudent fiscal policies and other progresses achieved in economic restructuring have contributed to macroeconomic and monetary stability. The inflation rate declined significantly to about 5 percent in 2003, from an average of 10 percent over the 2000-2002 period. Consequently, these conditions provided adequate room for monetary policy to consistently adjust interest rates in order to support further economic recovery process.

\section{Prudent Fiscal Policy Support the Effort to Stabilize the Economy}

Three decades of prudent fiscal management had resulted in a very low public debt in Indonesia, prima-

\footnotetext{
${ }^{3}$ Law No. 23, May 1999, available on the BI website www.bi.go.id. As amended in February 2004 in Bank Indonesia Law No. 03/2004, inflation rate target is set by the Government (Minister of Finance) after consultation with Bank Indonesia, and hence remove the "goal independence."
} 
Gadjah Mada International Journal of Business, May-August 2005, Vol. 7, No. 2

rily external debt. This trend was reversed when the crisis occurred. There was an adjusted and less restrictive fiscal framework, resulting in fiscal deficits largely financed by external sources. This expansionary fiscal stance was mainly caused by the huge costs of bank restructuring and recapitalization, negative impact of devaluation on external commitments and Social Safety Net measures for the poor. This inevitably led to the increase in the government debt, as depicted in the table below. It is clear that the economic crisis has constrained government budget developments, which experienced substantial increase in budget deficit, from 2.5 percent in 1997 to 5.7 percent in 1998 .

On the expenditure side, a huge amount of Fixed Rate Bonds (FRB) with maturity between 3 to 10 years were issued to increase banks' Capital
Adequacy Ratio (CAR) up to 4 percent, while Variable Rate Bonds (VRB) were issued to increase banks' negative CAR to 0 percent. Government also issued Hedge Bonds (HB) to cover banks' liabilities in foreign currency, revalued quarterly to reflect the rupiah/dollar exchange rate. On top of that, and not included in the public debt position, are the contingent liabilities associated with the Blanket Guarantee program provided to the banking system, which was introduced January 1998 to stop bank run and restore public confidence to the banking system. As discussed in section 2, the financial crisis has reversed Indonesia's track record of steady poverty reduction for decades, increasing the poverty rate from 11.3 percent in 1996 to 23.6 percent in 1999 , destabilizing the socio-economic condition. A huge amount of government expen-

Table 5. Government Bonds Portfolio (in trillion Rp)

\begin{tabular}{|c|c|c|c|c|c|c|c|}
\hline & 1999 & & 2000 & 2001 & 2002 & 2003 & \\
\hline & Outstanding & $\%$ & & & & Outstanding & $\%$ \\
\hline Based on Serial & 281.8 & 100 & 431.8 & 435.3 & 419.3 & 403.4 & 100 \\
\hline FixedRate & 51.2 & 18.2 & 179.4 & 175.4 & 154.4 & 159.0 & 39.4 \\
\hline Variable Rate & 203.9 & 72.3 & 219.5 & 219.5 & 239.6 & 231.4 & 57.4 \\
\hline Hedge Bond & 26.6 & 9.5 & 32.8 & 40.4 & 25.3 & 12.9 & 3.2 \\
\hline Based on Ownership & 281.8 & 100 & 431.8 & 435.3 & 419.3 & 403.4 & 100 \\
\hline Recap. Bank & 281.8 & 100 & 423.0 & 396.6 & 359.8 & 307.0 & 76.1 \\
\hline Non-Recap.Bank & - & & 6.6 & 24.8 & 13.8 & 27.4 & 6.8 \\
\hline Sub-Registry & - & & 1.8 & 13.0 & 44.8 & 68.9 & 17.1 \\
\hline Traded in Sec.Market & - & & 31.6 & 64.6 & 99.7 & 190.5 & 47.2 \\
\hline Total & 281.8 & 100 & 431.8 & 435.3 & 419.3 & 403.4 & 100 \\
\hline
\end{tabular}

Source: Bank Indonesia 
Goeltom-Balance Sheet Vulnerability and Macroeconomic Management in Indonesia

ditures were allocated for a Social Safety Net Program, among others by direct aid to help the poor meet their basic needs and providing direct credit to Small Farmers Cooperatives (KUT) and Small Trade Cooperatives (KUD) through the Ministry of Cooperatives and Small Scale Business (Table 5).

The fiscal deficits, which were largely financed by inflows of official capital from abroad, have led to higher public debt. In the immediate future, the pressing problem for the government is how to service this higher public debt. This will exacerbate pressures on the government budget, which has already been weakened by declining tax revenues, high interest payments and large energy subsidies. In this regard, despite efforts to raise taxes and improve tax administration, a de- cline in economic activity caused the drop of non-oil revenues from 13.1 percent (of GDP) in 1997 to 11.9 percent in 1998. Fortunately, external factors such as declining interest rates and higher oil prices provide some reprieve (Kuncoro 2004).

To remedy budgetary pressures, which are expected to continue in the following years, a range of pre-emptive budget actions is being undertaken, among others macro stability programs. On the revenue side these include raising tax revenues especially from the removal of VAT (value added tax) exemptions, better tax and customs administration, and reduction in tax incentives. Meanwhile, on the expenditure side, they include cutting expenditures on untargeted subsidies like energy and interest rate subsidies.

Table 6. Revenues and Expenditure in Indonesia (as \% of GDP)

\begin{tabular}{|c|c|c|c|c|c|c|}
\hline \multirow{2}{*}{ Year } & \multicolumn{3}{|c|}{ Revenue } & \multirow{2}{*}{$\begin{array}{c}\text { Total } \\
\text { Expenditure }\end{array}$} & \multirow{2}{*}{$\begin{array}{l}\text { Budget } \\
\text { Deficit }\end{array}$} & \multirow{2}{*}{$\begin{array}{c}\text { Foreign aid / } \\
\text { Borrowing }\end{array}$} \\
\hline & $\begin{array}{c}\text { Non- } \\
\text { oil }\end{array}$ & Oil \&Gas & Total & & & \\
\hline 1994 & 13.8 & 3.5 & 17.4 & 19.6 & -2.2 & 2.6 \\
\hline 1995 & 12.5 & 3.5 & 16.1 & 17.4 & -1.4 & 2.0 \\
\hline 1996 & 12.7 & 3.8 & 16.5 & 18.5 & -2.0 & 2.2 \\
\hline 1997 & 13.1 & 4.9 & 18.0 & 20.5 & -2.5 & 2.3 \\
\hline 1998 & 11.9 & 4.2 & 16.1 & 21.8 & -5.7 & 5.7 \\
\hline 1999 & 13.0 & 5.0 & 18.0 & 21.9 & -3.9 & 3.9 \\
\hline 2000 & 9.3 & 5.5 & 14.8 & 15.9 & -1.2 & 0.7 \\
\hline 2001 & 12.8 & 5.1 & 17.9 & 20.3 & -2.4 & 0.6 \\
\hline 2002 & 13.0 & 5.5 & 18.5 & 20.0 & -1.5 & 0.4 \\
\hline 2003 & 13.5 & 5.5 & 19.1 & 21.2 & -2.1 & 0.2 \\
\hline
\end{tabular}

Source : Ministry of Finance 
Gadjah Mada International Journal of Business, May-August 2005, Vol. 7, No. 2

In fact, such actions have brought about significant positive results, not only in terms of the declining budget deficits, but also creating sound environment for economic recovery process. Table 6 depicts the progress achieved, with budget deficits substantially declining from 5.7 percent in 1998 to 3.9 percent in 1999, and 1.1 percent in 2000. Further promising situation for fiscal sustainability was reflected by the low budget deficit during 2002 and 2003, which reached 1.8 percent and 1.6 percent, respectively.

The question is then whether the deficit can be sustained. Mahi and Jasmina (2000) estimated a fiscal sustainability model for Indonesia. They found that the level of actual operational deficit as a percentage of GDP during 1990-1998 was lower or at the same level of sustainable operational deficit, with 1990 as exception. This means that the required deficit reduction must be close to zero. One can thus conclude that during those years, the government successfully achieved a sustainable level of foreign public debt. One special case is in 1998 where the actual operational deficit jumped to 8.6 percent while the sustainable level required no more than 5 percent of GDP. This is not surprising since in 1998 the economic crisis was at its worst.

Another agenda was related to the central and local government relationships. Before 2000, for about thirty years, Indonesia has been known for its highly centralized fiscal system. The proportion of total revenues raised by local governments was very low by international standards. Using 19821983 fiscal years as an illustration, the transfer from the central government was more than 60 percent of provincial government routine revenues. Meanwhile, within the development budget, the largest contribution came from the central government's capital transfer, which accounted for around 40 percent of the provinces' development revenues. A similar pattern can be observed for district government, where about 50 percent of their routine budgets and 39 percent of their development budget were provided by the central government (Alisjahbana 2000).

\section{Efforts to Revive the Banking Sector}

Banking industry is one of the sectors hardest hit by the crisis and remained under downward pressure. The frail banking structure as a result of internal deficiencies was exacerbated by adverse external forces, such as exchange rate turbulences, high interest rates, social and political uncertainty, and a wide range of negative rumors that triggered bank runs. The depreciating rupiah, followed by rising interest rates due to policy tightening to stabilize prices and the exchange rate encountered banks with a negative net interest margin. The negative spread caused further losses and reductions of bank equity capital. The high interest rate environment interrupted the intermediary function of the banks as they faced onerous difficulties in extending credit. 
Goeltom-Balance Sheet Vulnerability and Macroeconomic Management in Indonesia

Settlement of the banking issue had to initially address the structural internal deficiencies. The low level of competence and integrity of bank management resulted in poor risk management as highlighted by numerous violations of prudential principles, high-risk investments and imprudent funding strategy. Added to these internal weaknesses was an emphatically inadequate internal control. Accordingly, banks' performance was in shambles, as reflected in their unbalanced balance sheet in both asset and liability sides.

On the asset side, the main problem was the deteriorating quality of productive assets. This problem originated from credit lending that was not based on sound lending criteria. Excessive credits were extended to certain groups and banks' subsidiaries in the form of connected lending that resulted in numerous violations of the legal lending limit. Another major problem came from a large portion of lending to high-risk sectors, most notably property. On the liability side, the main problem was a mismatch of currencies and maturities with shortterm un-hedged foreign loans used to finance long-term rupiah-generating projects. In addition, the negative spread during the reporting period magnified the substantial loss from the mismatch and introduced a larger retained loss in the thin equity base of the banks. Consequently, banks became considerably more susceptible to disruptive changes.
The internal deficiency in the banking industry was also associated with ineffective banking supervision. There were five constraints that shaped the ineffectual bank supervision. First, insufficient number of supervisors. Second, inadequate early warning systems. Third, a conflicting dilemma between consistent implementation of the regulations and concerns over likelihood of systemic failures. Fourth, the absence of standard operating procedures to exercise exit policy (a policy that describes ways for any bank to exit from the banking system) that had in fact resulted in moral hazard. Fifth, frequent interference from connected parties that hindered any policy remedy from materializing.

Banking restructuring program has been implemented into various comprehensive and concrete actions under a new sound and sustainable banking system, restore public confidence on national banking system and revitalize its function as financial intermediation institution. Banking restructuring to date has involved closure of unviable institutions, mergers of the banks taken over, removal of non-performing loans from banks' balance sheets, and recapitalization of banks under the Indonesian Bank Restructuring Agency (IBRA). In essence, the Government, jointly with Bank Indonesia, has taken strategic and comprehensive policies aiming at restoring public confidence, both domestically and internationally, toward the Indonesian banking industry and 
Gadjah Mada International Journal of Business, May-August 2005, Vol. 7, No. 2

at encouraging the bank restructuring process. Those policies include: (i) the in-troduction of a Government Guarantee Scheme, (ii) the establishment of IBRA, (iii) the recapitalization of banks, and (iv) corporate sector restructuring (See Appendix 1).

Learning from the crisis, in addition to inadequate legal infrastructure to enforce banks' prudential principles, the lax enforcement of laws and regulations has also become an important source of banking problems. As a result, the Government and Bank Indonesia enacted several Acts and improved several prudential regulations in line with international standards and best banking practices. Throughout the crisis period, the Government has promulgated the Banking Act, the Central Bank Act, the Act of Foreign Exchange Traffic and Exchange Rate System.

In the same time, Bank Indonesia has legislated and amended various prudential regulations, aiming at providing a basis for good corporate governance. Bank Indonesia has also en- acted regulations pertaining to the banking institutional framework. Such regulations govern the prerequisites of bank establishment, changes in bank organization and ownership, which are part of bank's entry criteria. Furthermore, an exit policy criterion was explicitly applied to banks under special surveillance by IBRA, while prompt corrective actions are to be taken within defined periods. Bank supervision strategies were improved in line with international standards.

As a result of the above measures, there have been significant changes in banks' balance sheets since 1999. The following figures compare the evolving composition of sources and uses of funds in the banking sector from 19942003 (Figure 4 and 5). In line with economic recovery and increased public confidence on the banking system, the Third Party Funding, which is dominated by Savings and Time deposits, has steadily increased while subsequently reducing offshore and interbank borrowing. This encouraging de-

Figure 4. Banking Sector Sources of Funds (\%)

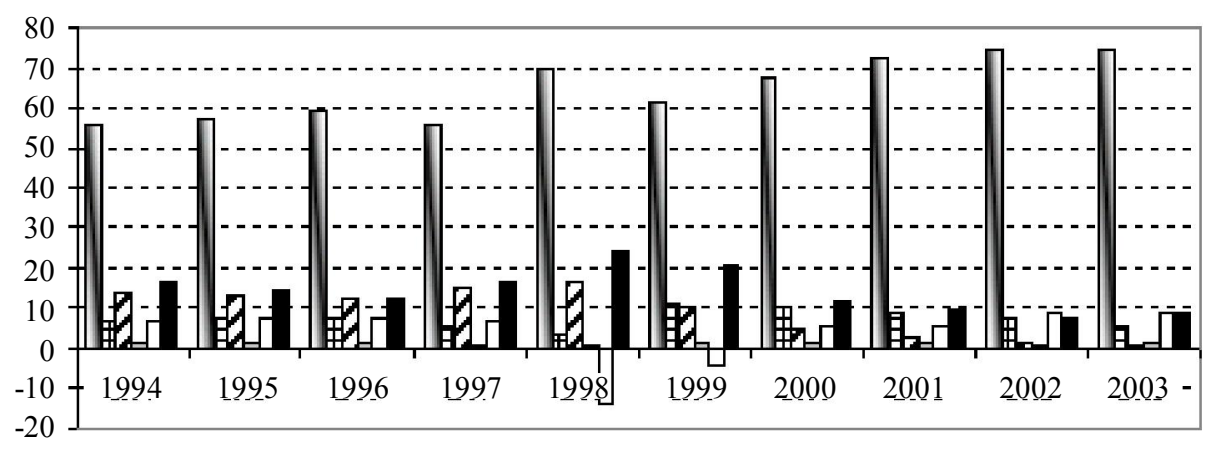

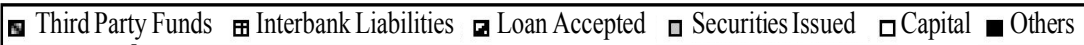


Figure 5. Banking Sector Uses of Funds (\%)

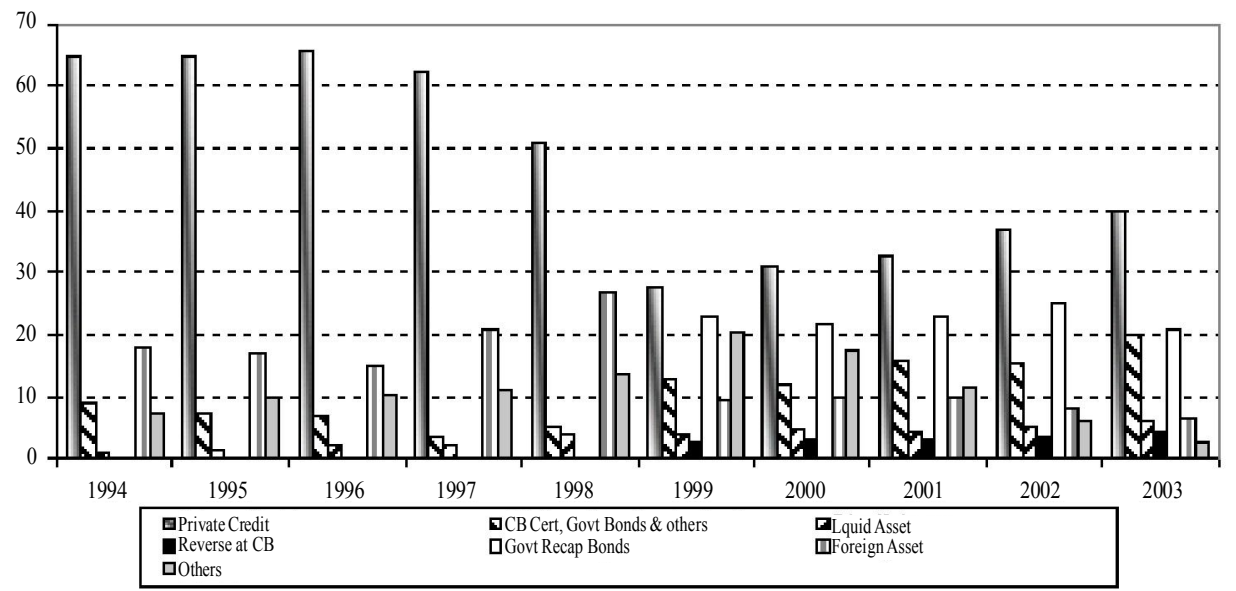

Source: Bank Indonesia

velopment in the liabilities side was further strengthened by the increasing capital base of the banking system, from negative 41 trillion rupiah (approximately USD 500 billion) by the end of 1999 to a positive 110 trillion rupiah (approximately USD 1200 billion) by 2003. As a result, shown in the earlier figures, the Non Performing Loan declined substantially to a low 5 percent in 2003.

On the other hand, private credit, which was mainly consumer's credit, has also moved in the same higher direction, with the decline in other assets. However, the structure of the asset side of the banking system was still overwhelmed by the Government Recap Bonds, which, until late 2002, were practically illiquid. Only after the creation of a Debt Management Unit under the Ministry of Finance, trading of Recap Bonds started to in- crease gradually, resulting in a declining shares of Government Bonds in the Banking Assets.

\section{Corporate Restructuring}

Efforts to restructure the banking system were then complemented by steps to restructure distressed corporations. Three agencies, namely IBRA, Indonesian Debt Restructuring Agency (INDRA), and Jakarta Initiative Task Force (JITF) have been assigned to conduct corporate restructuring. In addition, Bank Indonesia has also instituted a special Task Force dealing with Loan Restructuring and Optimization, functioning as facilitator between debtors and creditors. Its activities involve providing debtor information, arranging meeting between creditors and debtors, acting as mediator and observer, and providing technical assistance. 
Gadjah Mada International Journal of Business, May-August 2005, Vol. 7, No. 2

As an alternative approach to resettle private debts outside the banking system, the Government established INDRA. Basically, this scheme offers Forward Foreign Exchange Cover, provided that debtor companies have serviced their monthly obligation in rupiah through INDRA, at a favorable exchange rate based on twenty-day moving averages. Under INDRA, corporate debt is rescheduled with interest payments paid in rupiah with a three-year grace period, while the principal is to be paid on the fourth up to the eighth year.

Meanwhile, an additional framework called "The Jakarta Initiative" was launched to complement the newly amended bankruptcy law and facilitate the bankrestructuring agenda along with the INDRA scheme. This framework contains principles to resolve private sector debt problems through an out-of-court resolution with creditors so that these companies might have access to working and new capital. The Jakarta Initiative includes: (i) facilitating out-of-court negotiations; (ii) providing a forum for expedited "one-stop facilitation" of all regulator filings necessary to implement a restructuring plan; and (iii) providing recommendations on any legal, regulatory, or administrative changes needed to further facilitate corporate restructuring. Assistance to the Jakarta Initiative is to be provided by the World Bank, along with targeted assistance to small and medium-size enterprises by the ADB.

It is worthy to note that although both INDRA and JITF were considered ineffective due to their voluntary natures, somehow the gradual improvement in macro-economic fundamentals have brought about a better capacity for the corporate sectors to tap other funding sources.

Figure 6 and Figure 7 compare the evolving composition of sources and

Figure 6. Corporate Sector Uses of Funds (\%)

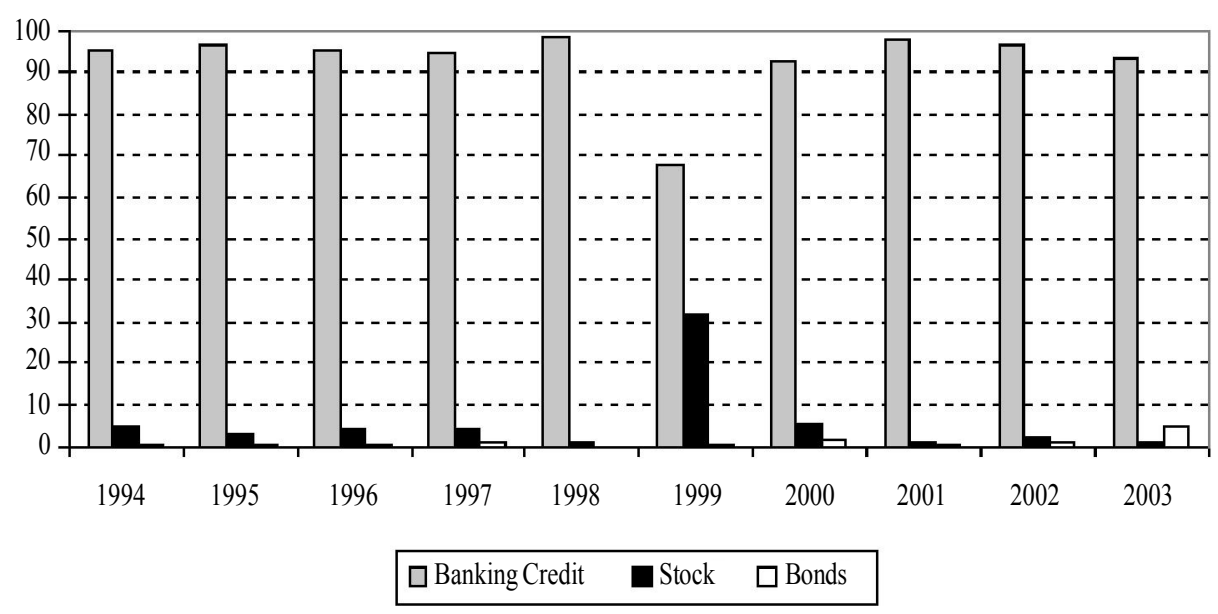


Goeltom-Balance Sheet Vulnerability and Macroeconomic Management in Indonesia

Figure 7. Corporate Sector Sources of Funds (\%)

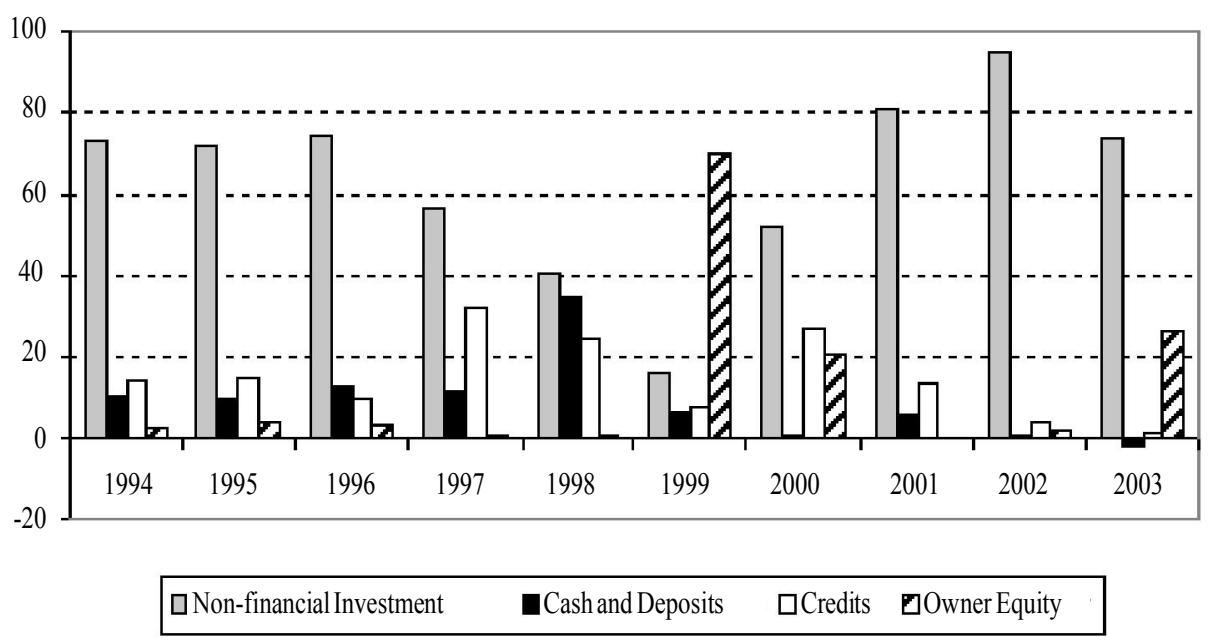

Source: Bank Indonesia

uses of funds in the corporate sector from 1994-2003. Figure 6 shows that before the crisis, private sector funding came primarily from banking credit. The 1997 crisis which was followed by subsequent credit crunch forced the corporate sector to rely more on non-bank financing sources, mainly by issuing stocks, and gradually move to issuemore bonds following the emergence of a government bonds yield curve. On the other hand, the strike of crisis was noticed significantly on the sharp decline of (non financial) investments. Meanwhile, Figure 7 shows that during the peak of crisis period, investment continuously declined and reached its lowest level in 1999. It is interesting to note that, in the same period, corporate sector tended to hold cash/deposits and even spent expenses for building up owner equity. This shifting was only temporary in nature, since in line with the economic recovery, investment rose gradually to higher levels than before the crisis.

From previous exploration, it can be noted that while household sector was the only sector which always experienced surplus during the 19942003 period, it seems that this was also a substitution of declining performance of corporate businesses. Therefore, it worth observing household sector's behavior during the crisis. In this regard, Figure 8 depicts household sector expenses structure from 1994-2003. It can be seen that, compared to the pre-vious years, in 1997 this sector spent more funds on insurance and pension activities and, on the other hand, held less cash and deposits. When the crisis reached its highest momentum, during 1998 and 1999, household expenses on credits to other sectors in the economy gradually increased and 
Figure 8. Household Sector Expenses Structure (\%)

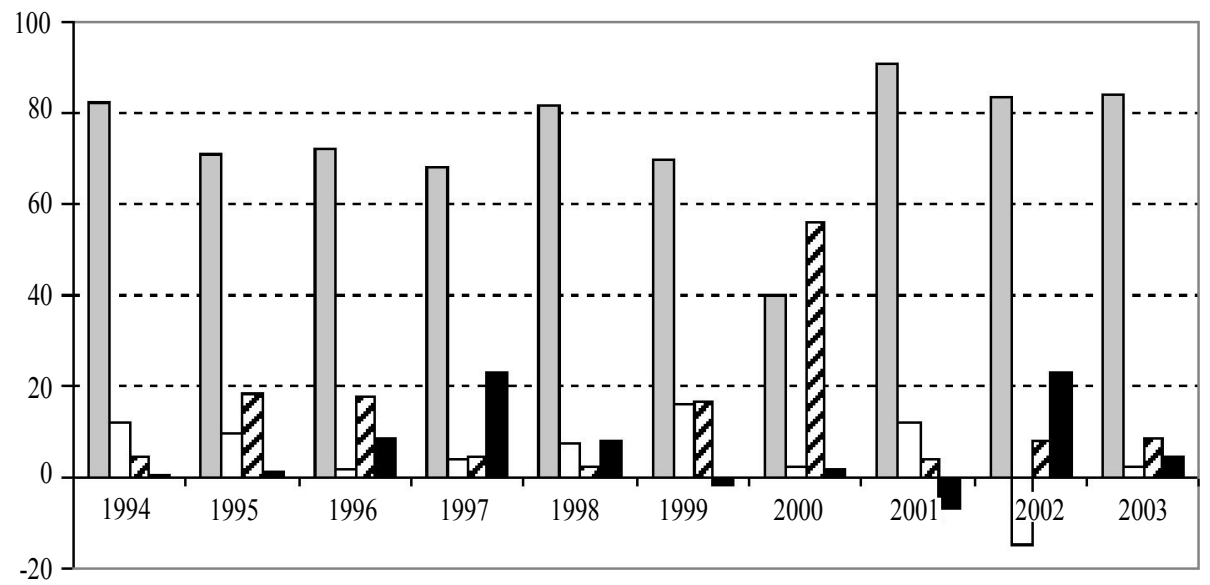

$\square$ Cash and Deposits $\quad \square$ Credits $\quad \mathbf{a}$ Owner Equity $\quad \square$ Insurance and Pension

Source: Central Statistic Board (Flow of Fund Data)

reached their highest level. Meanwhile, besides cash and deposits, owner equity on business sectors was still recognized as a preferable option during economic recovery process.

\section{External Debt Restructuring}

Until the crisis hit the country in 1997, total national debt has accelerated significantly (Table 7 and Table 8 ). The ratio of private sector debt to total national debt increased steadily from 12.6 percent in 1980 , to 29.5 percent in 1990 and 81 percent in 1998. The financial crisis in 1997 reversed the trend, and private debt declined to 20 percent in $2003 .{ }^{4}$ On the other hand, public foreign debt increased signifi- cantly during the crisis, mainly due to the increase of IMF loan from 1997 to 2000 by USD 3,03 billion equivalent, USD 5,8 billion, USD 1,4 billion and USD 1,1 billion respectively. By 2004, total loans from IMF reached USD 11.3 billion.

As the economy was in the brink of collapse, for the first time in our history, on September 23, 1998 the government entered a negotiation under the auspices of Paris Club creditor nations which had agreed to reschedule $\$ 4.4$ billion in principal payments. The principal of Official Development Assistance loans was rescheduled with a twenty-year maturity and a five-year grace period, while export credits were

\footnotetext{
${ }^{4}$ Since mid 2003, Indonesian blue chip corporates such as Medco and Indofood, as well as some State Banks such as Bank Mandiri and Bank BNIwent back to the international market by issuing bonds or Floating Rate Notes (FRN).
} 
Goeltom-Balance Sheet Vulnerability and Macroeconomic Management in Indonesia

Table 7. Indonesian Total Foreign Debt (Percentage)

\begin{tabular}{|c|c|c|c|c|c|c|c|c|c|c|c|}
\hline Indicators & 1994 & 1995 & 1996 & 1997 & 1998 & 1999 & 2000 & 2001 & 2002 & 2003 & $\begin{array}{c}\text { World Bank } \\
\text { Criteria }\end{array}$ \\
\hline Debt Service Ratio & 35.9 & 30.3 & 35.9 & 44.5 & 57.9 & 56.8 & 41.1 & 41.4 & 33.1 & 27.1 & 20 \\
\hline Total Debt to Export & 230.7 & 227.2 & 232.9 & 207.3 & 261.8 & 252.1 & 191 & 200.7 & 193.9 & 188.6 & $130-220$ \\
\hline Total Debt to GDP & 55.7 & 64.8 & 65.1 & 62.2 & 146.3 & 105 & 93.8 & 91.1 & 76 & 62.9 & $50-80$ \\
\hline
\end{tabular}

Source: Bank Indonesia

Table 8. Indonesian Total Foreign Debt by Sector

(Billion USD)

Private Debt

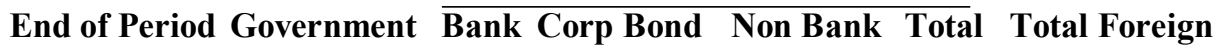

\begin{tabular}{|c|c|c|c|c|c|c|}
\hline & Debt & & & & & Debt \\
\hline 1994 & 58.6 & 8.6 & 1.4 & 28.3 & 38.3 & 96.9 \\
\hline 1995 & 59.6 & 10.1 & 1.9 & 36.3 & 48.2 & 107.8 \\
\hline 1996 & 61.9 & 9.0 & 2.4 & 43.4 & 54.9 & 116.7 \\
\hline 1997 & 53.9 & 14.4 & 10.3 & 57.6 & 82.2 & 136.1 \\
\hline 1998 & 67.3 & 10.8 & 2.1 & 70.7 & 83.6 & 150.9 \\
\hline 1999 & 75.9 & 10.8 & 1.0 & 60.4 & 72.2 & 148.1 \\
\hline 2000 & 74.9 & 7.7 & 1.2 & 57.9 & 66.8 & 141.7 \\
\hline 2001 & 71.4 & 6.6 & 1.1 & 53.9 & 61.6 & 133.0 \\
\hline 2002 & 74.7 & 4.9 & 2.8 & 44.4 & 52.0 & 126.7 \\
\hline 2003 & 81.7 & 4.3 & 1.8 & 32.2 & 38.3 & 120.0 \\
\hline
\end{tabular}

(Percentage of GDP)

Private Debt

End of Period Government Bank Corp Bond Non Bank Total Total Foreign

\begin{tabular}{|c|c|c|c|c|c|c|}
\hline & Debt & & & & & Debt \\
\hline 1994 & 33.7 & 4.9 & 0.8 & 16.3 & 22.0 & 55.7 \\
\hline 1995 & 35.8 & 6.0 & 1.1 & 21.8 & 29.0 & 64.8 \\
\hline 1996 & 34.5 & 5.0 & 1.3 & 24.2 & 30.6 & 65.1 \\
\hline 1997 & 24.6 & 6.6 & 4.7 & 26.3 & 37.6 & 62.2 \\
\hline 1998 & 65.3 & 10.5 & 2.0 & 68.5 & 81.0 & 146.3 \\
\hline 1999 & 53.8 & 7.7 & 0.7 & 42.8 & 51.2 & 105.0 \\
\hline 2000 & 49.6 & 5.1 & 0.8 & 38.3 & 44.2 & 93.8 \\
\hline 2001 & 48.9 & 4.6 & 0.7 & 36.9 & 42.2 & 91.1 \\
\hline 2002 & 44.8 & 2.9 & 1.7 & 26.6 & 31.2 & 76.0 \\
\hline 2003 & 42.8 & 2.3 & 0.9 & 16.9 & 20.1 & 62.9 \\
\hline
\end{tabular}

Source: Bank Indonesia 
rescheduled with an eleven-year maturity and a three-year grace period. A milestone agreement on Indonesian private debt restructuring was reached in Frankfurt in June 1998. The Frankfurt agreement covered three areas: inter-bank debt, trade maintenance facilities, and corporate debt. With respect to the inter-bank debt, a settlement of \$3.02 billion bank obligations falling due prior to April 1, 1999 were replaced by new loans guaranteed by Bank Indonesia with payment tranches of one, two, three, and four years.

In addition, a second restructuring step was announced by the London Club Steering Committee in March 1999 , in which another $\$ 3.3$ billion of eligible debts owed by Indonesian banks falling due within April 1, 1999 until December 31, 2001 (excluded payment as a result of previous exchange offer) has been tendered by creditors. The eligible debts were reconciled and exchanged for new loans under Bank Indonesia guarantee for default payment with four types of tranche maturities and the first payment for the new loan will be due on 2002. As of July 6,1999 , out of $\$ 3.3$ billion outstanding debts, $\$ 3.2$ billion has been reconciled and exchanged.

As regards to trade maintenance facilities, individual foreign banks agreed to maintain their trade financing facilities amounting to $\$ 2.9$ billion with guarantee from Bank Indonesia. This agreement became effective as of April 1998. As of June 8, 1999, the outstanding facility has reached $\$ 1.1$ billion. Trade maintenance facilities were extended up to June 2000, which covers guarantee of trade maintenance facilities up to December 2000. Furthermore, to maintain sustainability of export performance, Indonesia has established a co-operation with 7 international export credit agencies, namely Japan EXIM, GSM USA, CWB Canada, US EXIM bank, ECGD UK, EDC Canada, and KFW Germany. In total this facility amounted to roughly $\$ 2.6$ billion. More recently, a legal framework to operate a newly Indonesia's Export Bank was established. This agency is designed to support the financing of export activities in Indonesia. These debt restructuring programs have allowed the country to allocate its limited resources to fund the bank recapitalization and Social Safety Net program.

\section{Preliminary Result: Improving Macroeconomic Indicators}

The results of this economic adjustment and reform program, while painful, are increasingly well known. There has been a major progress in the restoration of macroeconomic stability, supported by sound monetary policies. The risk of deepening hyperinflation in 1998 was averted and inflation has since abated. The rupiah has strengthened and exchange rate stability was restored in a free market environment. Consistently with the renewed macroeconomic balance, pressures on interest rate abated along with improvement in risk premium, a steady 
Goeltom-Balance Sheet Vulnerability and Macroeconomic Management in Indonesia

appreciation of rupiah, increase in foreign exchange reserves to a highrecord, and of share values on the Jakarta Stock Exchange (JSX). With the restored macroeconomic stability and renewed business confidence, signs of incipient recovery in the real economy take place and the GDP gradually rebounds, confirmed by improved leading indicators. The economic recovery, while still fragile and beset with uncertainties, appears to be ongoing and widening its base. (See also Appendix 2)

\section{Balance Sheet Vulnerability and Management Post IMF Program}

As investigated in the previous section, most sectors were still vulnerable to common shocks. This vulnerability was not only reflected by fluctuations in the net borrowing of these sectors, but also cyclical patterns in the net borrowing of the whole economy. Under such condition, small shocks that hit the banking sector, for instance, might be spread substantially to the whole economy. Therefore, to maintain strong economic performance ahead, preemptive sound macroeconomic policies must be implemented consistently. In addressing what factors affecting balance sheets vulnerability and how these conditions would impact the economy is not an easy task and is a part of a long research agenda. Without loss of generality, this section addresses two related issues, namely the behavior of asset market dynamics and the monetary policy transmission mechanism.

\section{Asset Market Dynamics and Monetary Policy: Preliminary Investigation}

The asset market dynamics, reflected by the movement of asset price index, could be related to balance sheet developments and financial stability, thus economic performance as a whole. The experiences from other countries indicate co-relationship between asset prices and financial stability. From theoretical perspectives, asset price fluctuation may cause balance sheet performance, and consequently affect investment decisions. Therefore, it is important to carefully examine the impact of asset price movements on various economic sectors if stability is to be maintained.

Complications in the above issues emerge in the context of the unique characteristics of the Indonesian economy. As explored in the previous section, the Indonesian economy still experiences "staggered" recovery while most sectors were vulnerable to further common shocks. Consequently, it is very difficult to predict how large asset market dynamics affect the economy, and therefore their role in macroeconomic management design. The following section will explore a preliminary investigation on asset market dynamics and a broad scope of macroeconomic policies towards maintaining stability during the post crisis period. 
Gadjah Mada International Journal of Business, May-August 2005, Vol. 7, No. 2

Despite significant impact of asset market dynamics on the Indonesian economy, asset prices in Indonesia traditionally do not play a prominent role as important indicators in the design of macro (monetary) policy. Unlike developed countries, Indonesian Capital Markets are still far from mature. As a result, the role of asset price development was quite insignificant to monetary policy decision-making process. Consequently, the role of asset prices in the transmission process of monetary policy was largely disregarded. From a preliminary study on asset market dynamics, stock prices (JSX) in particular are considered to contain less valuable information in the final target of monetary policy. The fact that non-residents hold 67 percent of stocks issued, and that only 70 thousand (or $0.03 \%$ of total population) investors are registered at the Indonesian Central
Securities Depository might explain the failure of JSX index in transmitting monetary policy to its final target (Warjiyo and Agung, 2001). However, the increased financing to property sector and improved role of the capital market implicitly send a signal to monetary policy makers to reconsider the dynamics of asset prices in the formation of monetary policies. In this respect, asset prices in particular are thought to contain valuable information and therefore should have been taken into account in conducting monetary policies.

As a result, a composite asset price index was constructed and is composed of several assets holding, namely residential assets, commercial asset and equity. The result of construction of asset price index is demonstrated in Figure 9.

Figure 9. Indonesia Composite Asset Price Index

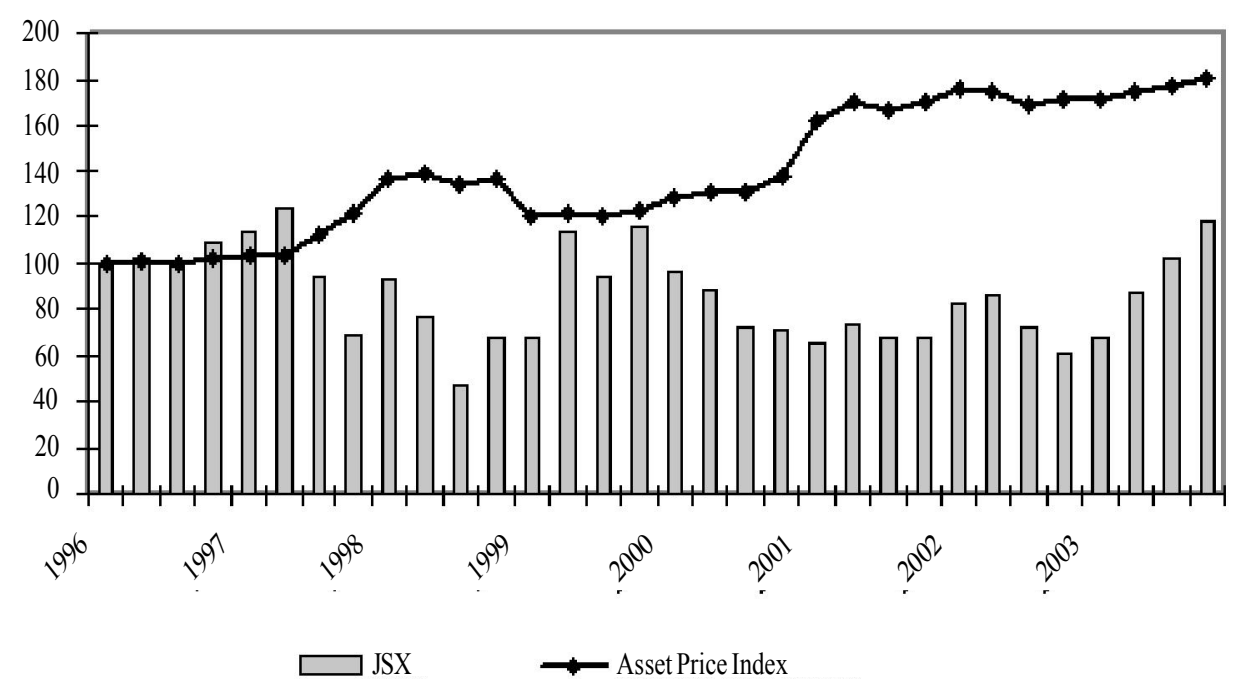

Source: Bank Indonesia 
Goeltom-Balance Sheet Vulnerability and Macroeconomic Management in Indonesia

Up to mid 1997, the increase in the asset price was in line with the period of high economic expansion. Extensive credit lines, especially to the property sector, boosted up the price of land, housing and commercial properties. Many new residential estates were developed throughout big cities along side with the construction of high-rise office buildings. This created a so-called bubble in the economy. As the market will correct any deviation from fundamentals, so was this asset price movement. The economic crisis crashed the property sector and prices dropped severely. However, as the leading sector in the expansion period is improving, the hope of recovery created confidence towards the Indonesian economy. This positive expectation was mirrored in the increasing price of asset.

Meanwhile, the results of the study concludes that when the role of composite asset price index in monetary policy transmission is questioned, the results signify the existence of asset price channel of monetary transmission through both consumption and investment channels. Also, the information content of inflation (the final target of monetary policy) that can be explained by changes of monetary policy through asset price channel using investment path is slightly higher than that of consumption path. The slightly lower information content through consumption channel might relate to the long lags substitution effect.
The Impact of Balance Sheet Adjustment on Monetary Policy Transmission

Looking at the sectoral level, banks' behaviors in making balance sheet adjustments by selecting their portfolio compositions can also play an important role in explaining monetary policies transmission (Silber 1969, and Beckhart 1940). Within banks' portfolio, a special attention has been given to credits, as this type of asset will be the most dominant portfolio in a normal and well functioning bank. The growing awareness of the importance of credit in monetary policy transmission process is driven among others by concerns over the impact of financial sector weaknesses, bank failures, non performing loans (NPLs), and credit rationing on the effectiveness of the transmission process (see e.g., Blinder (1987), Bernanke and Blinder (1988), Brunner and Metzler (1988)). In the past, monetary literature had paid little attention on the role of credit due to the emergence of monetarist thinking and the overriding influence of Keynesian thought on "Liquidity Preference" that stressed the importance of money rather than credit (Gertler (1988). As proposed by Stiglitz and Greenwald (2003), a new monetary policy paradigm should really be re-focusing its attention toward the importance of supply and demand for credits into the economy. 
Gadjah Mada International Journal of Business, May-August 2005, Vol. 7, No. 2

Within this context, this section tries to overview the implication of banks' behavior in adjusting their balance sheets on the effectiveness of monetary policies in Indonesia. ${ }^{5}$ Alamsyah and Goeltom (2004) noted that during the peak of the crisis, there are strong indications that the effectiveness of monetary policy transmission via banking channel had been significantly lower, with, for instance, a smaller sensitivity of loan rates to changes in SBI rates during the crisis as compared to pre crisis period. Two major factors are responsible for this condition. First, economic crisis and its impact on mounting NPLs had increased banks' perception on default risks very significantly. This factor reduced banks' willingness to increase loan rates as a respond to higher policy rates in order not to worsen their NPLs. Second, as most borrowers experienced huge solvability problems, they became more sensitive to loan rate changes. This factor reduced banks' ability to increase loan rates without losing their good customers. Both factors were so dominant that they overshadowed the incentive to increase loan interest revenues to cover the losses from higher NPLs .

As borrowers were more sensitive to loan rate changes and banks suffered huge losses from higher NPLs, the negative impact of higher policy rates on loans volume were larger during crisis. Meanwhile, as default risks were substantially high, the opportunity cost of extending credit was higher than the opportunity cost of holding idle fund (fund "trapped" in bad debts, reserve requirement, and excess reserves). These made loan rates less sensitive to policy rates relative to deposit rates. Consequently, the increase in SBI rates increased deposit rates much faster than the increase in loan rates creating negative interest margin.

Furthermore, it can be shown also that the improvement of monetary policy transmission has been very slow during the post crisis period. The sensitivity of loan rates to policy rates changes increased only slightly, and still lower than the sensitivity during pre crisis period. Although banks' perception on default risk had improved significantly, banks were still very cautious as evidenced by higher CAR ratio than required by regulation. The positive income effect of smaller NPLs has also reduced the incentive for banks to fully respond any changes in policy rates. Both factors have resulted in slower decline of loan rates than the decrease in SBI rates during the period.

The sensitivity of loan volumes to policy rates changes has also been declining during the post crisis period, with even lower levels than during the pre crisis period. Banks are still very cautious in extending credits as evidenced in higher CAR ratio. In addi-

\footnotetext{
${ }^{5}$ A simple model of banking channel has been designed to address bank's behavior and is impact on monetary policy transmission during the crisis.
} 
Goeltom-Balance Sheet Vulnerability and Macroeconomic Management in Indonesia

tion to that, smaller NPLs ratio has reduced banks' loses significantly. This situation has reduced the need from banks to increase loan supply to cover losses from NPLs. On the other hand, as borrowers are not suffering from solvability problems so heavily as during peak crisis times, demand for loans is less sensitive to interest rate changes. Consequently, as the monetary authorities reduced the policy rates to boost aggregate demand, the increase is relatively slower than if the same policy were conducted pre crisis. Also, as banks are still maintaining higher CAR, the opportunity cost of extending credit is still higher than the opportunity cost of holding idle fund (which is declining as NPLs are smaller). This makes loan rates still less sensitive to policy rates relative to deposit rates. Consequently, lower SBI rates reduce deposit rates faster than loan rates (thepositive spread between both rates widens).

From the above exploration, it can be concluded that there are indications that bank's balance sheet adjustment, which has led to bank disintermediation, has reduced the effectiveness of monetary policies during the crisis and post crisis period. Structural changes and balance sheet adjustment in banks and borrowers have altered the smoothness and effectiveness of monetary policies. As banks are still the major source of financing in Indonesia, this situation contributes to the current slower pace of economic recovery compared to other countries that experienced similar crisis.
Macroeconomic Management to Strengthen Financial Markets

\section{Development of Bond Market}

Lack of diversified sources of funds and over-reliance on foreign capital flows, in particular the un-hedged private short-term borrowings in foreign currencies, have worsened the situation. As mentioned in the previous section, in Indonesia as in most of East Asia, the banking sector has been the major source of domestic financing. Capital markets have traditionally been embryonic, and in limited occasions issues got priced, in usual amounts. The inadequacies of Asia's capital markets have been the flipside of a dominant banking sector that has intermediated more than 80 percent of the region's investment, much more in the case of Indonesia, as shown in Figure 10. The Indonesian Government recognizes that rehabilitating the banking sector alone will not be enough to strengthen the financial system. It is also imperative to encourage efficient and diversified capital intermediation to ensure sustainable economic growth.

Even though capital markets and the banking sector were deregulated in swift reforms in 1988, bond markets in Indonesia have never been adequately developed, let alone liquid. Only in 1998, and as a consequence of the Asian Financial crisis, did the Government begin to issue Recapitalization Bonds. However, these instruments were issued solely to recapitalize the banking sector and to support Bank 
Gadjah Mada International Journal of Business, May-August 2005, Vol. 7, No. 2

Figure 10. Domestic Sources of Indonesian Economic Development (percent)

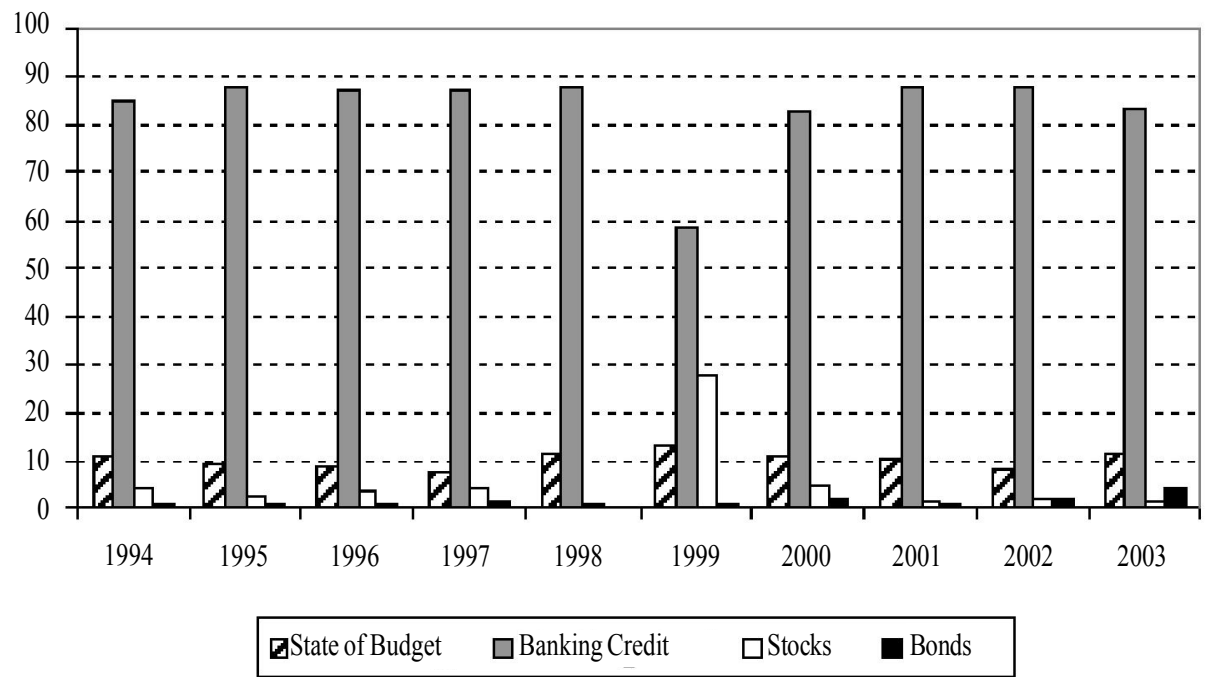

Source: Bank Indonesia, Ministry of Finance

Figure 11. Government Bond Maturity Profiles

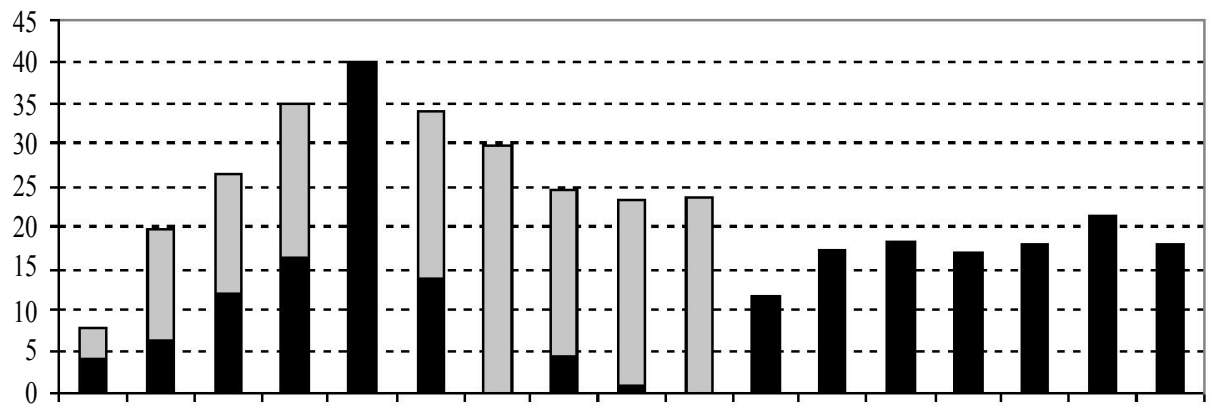
20042005200620072008200920102011201220132014201520162017201820192020

Source: Bank Indonesia

ロVariable Rate $\square$ Fixed Rate

Indonesia's Liquidity Support operations, and not to begin the process of building a domestic bond market. The securities were placed directly with the banks in exchange for non-performing loans and were not auctioned in the market. In fact, the necessary legal, settlement and clearing infrastructure did not exist at the time. This made trading difficult and most of the "recap" banks kept their bonds in their investment accounts.

Co ordination between the Central Bank, the Ministry of Finance and 
Goeltom-Balance Sheet Vulnerability and Macroeconomic Management in Indonesia

other supervisory agencies in designing the strategy to establish a welldeveloped and functioning Government bond market in the country is therefore vital. In line with stable stock market conditions in 2003, Government bonds market became more liquid and efficient. However, a close watch is still necessary due to re-financ-ing and under-subscriptions, which could erode government credibility and the sustainability of state budget financing. Recent developments (Figure 11) show that large amounts of Government bonds will mature in the 20042013 period, which narrows long-term options for Government bond refinancing. This was one of the factors behind several cases of under-subscription of Government bond issuance in 2003.

In line with the developments of the Government bond market, the corporate bond market has also improved markedly. This is evidenced by the rising value of new bond issuances and market capitalization. However, such rapid developments necessitate close monitoring due to potential and systemic risks. A sharp rise (of $60 \%$ ) in the corporate bond price index during 2003 made an important contribution to the Indonesian capital market. Liquidity in the corporate bond market has picked up in term of both price and value of bonds issued. However, a number of issuers had questionable fundamentals. In this regard, debt to equity ratios remained high in several sectors, such as textiles, property, and pulp and pa- per, suggesting continued vulnerability.

\section{Implementation of The Indonesian Banking Architecture}

The Architecture represents an urgent need for the Indonesian banking system in order to strengthen the fundamentals of the banking industry. The 1997 economic crisis demonstrated that Indonesia's banking industry lacked the proper institutional basis, and therefore requires strengthening of fundamentals to be able to withstand internal and external shocks. Lack of strong fundamentals in the banking system represents a challenge not only for the banking industry as a whole, but also for Bank Indonesia as the authority responsible for bank supervision.

Building a more robust banking system requires improvements to be made in many different areas, including: (i) Low capacity for growth in bank lending, (ii) Structural weaknesses, (iii) Banking services failing to satisfy public needs, (iv) Bank supervision, (v) Weak capabilities, (vi) Unsustainable profitability and operating efficiency levels, (vii) Customer protection, and (viii) Advancements in Information Technology.

To fulfill the vision and objectives of the Indonesian Banking Architecture and respond to the challenges confronting the banking system, the six pillars of the Indonesian Banking Architecture described above will be put into place through a number of work programs outlined as follows: 
Figure 12. Structure Envisaged for the Indonesian Banking System

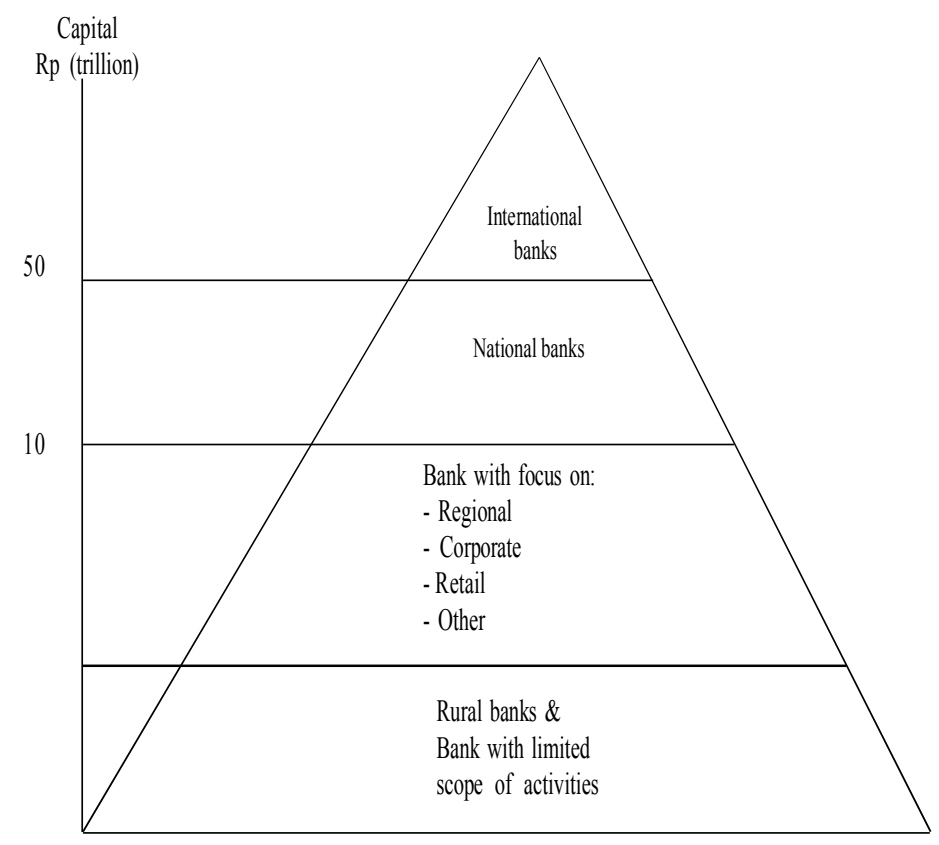

1. Program for reinforcing the structure of the national banking system. This program is aimed at reinforcing the capital of commercial banks (conventional and sharia) to strengthen bank capacity for business and risk management, develop information technology, and expand the scale of business in order to support increased capacity for bank credit expansion. In overall terms, the structure envisaged for the Indonesian banking system in the next ten to fifteen years is described as Figure 12.

2. Program for improvement in quality of banking regulation. This program is aimed at improving the effectiveness of regulation conducted by Bank Indonesia and achieving compliance with regulatory standards based on international best practices. The program can be achieved through improvements in bank policy-making processes and by phasing in the comprehensive application of the 25 Basle Core Principles for Effective Banking Supervision.

3. Program for improvement of the supervisory function. This program aims at improving the effectiveness and efficiency of bank supervision conducted by Bank Indonesia. This objective will be achieved by improving the competency of bank examiners, improving coordination among supervisory agencies, development 
Goeltom-Balance Sheet Vulnerability and Macroeconomic Management in Indonesia

of risk-based supervision, more effective enforcement and consolidation of the banking sector organization within Bank Indonesia.

4. Program for quality improvements in bank management and operations. This program is focused on improving good corporate governance, quality of risk management, and operational management capabilities. It is expected that higher standards of GCG supported by strong operational capability (including risk management) will lead to higher operating performance in the banking system.

5. Program for development of banking infrastructure. This program is aimed at developing supporting infrastructure for effective banking operations, such as a credit bureau, domestic credit rating agency and a credit guarantee scheme. Development of the credit bureau will assist the banking system in improving the quality of lending decisions. The use of credit rating agencies in publiclytraded debt held by banks will improve the transparency and effectiveness of bank financial management. Similarly, the development of a credit guarantee scheme will increase public access to credit.

6. Program for improvement of customer protection. This program is aimed at empowering customers through the establishment of a mechanism for customer complaints, establishment of an independent mediation agency, improved transparency of information on banking products and education to customers.

\section{Concluding Remarks}

The economic and financial crisis hitting Indonesia since mid-1997 has triggered a significant economic downturn. By examining balance sheet conditions across various sectors in the economy, it is shown that despite some progress, the overall balance sheet conditions are still vulnerable to further shocks. Hence, efforts to restore growth and stability still face great challenges. The vulnerability of balance sheet had propagation impacts to the whole economy. As experienced by Indonesia and other Asian countries, it has been empirically shown that the vulnerability of the corporate sector propagated to the banking sector as the key player in financial markets, and onto the other sectors. Therefore, an urgent action was implemented by the Indonesian macroeconomic policy makers focusing on the efforts to strengthen financial markets, among others, by developing bond markets and implementing a strong banking architecture.

The results are encouraging as shown by various macroeconomic indicators. Economic growth has continuously increased up to nearly 5 percent in 2003, while inflation reached a record low of 5 percent, exchange rate 
Gadjah Mada International Journal of Business, May-August 2005, Vol. 7, No. 2

has appreciated and stabilized at around Rp 8,800 per US dollar and the 1month interest rate Central Bank Certificate benchmark (SBI) declined to a historical low of 7.4 percent.

However, various constraints remain and the recovery process is yet to be accelerated. The banking system is still struggling to improve its risk management capacity, with a remaining reluctance to restart lending and a preference towards investment in Government Bonds and Central Bank Certifi- cates. The challenge is to speed up institutional reform so that credit lending and other funding sources can resume to support higher investment growth. Debt restructuring and structural reform will have to be pursued in order to avoid the same recurrence of crisis. Policy coordination in developing the bond market and conducting prudent monetary and fiscal policies is equally crucial, but is fortunately legally supported and benefits from an independent Central Bank.

\section{References}

Alamsyah, H., and Miranda S. G. 2004. Bank Disintermediation and Its Implication to Monetary Policy: The Case of Indonesia. Jakarta, Indonesia: Directorate of Economic Research and Monetary Policy Department, Bank Indonesia.

Alisjahbana, A. S. 2000. Local Government on Revenue Mobilization", paper presented at the Indonesian Economic Recovery in Changing Environment Conference, September, Jakarta.

Bank Indonesia. 1999. The Law No. 23 Regarding to Bank Indonesia (May). Available on the BI website www.bi.go.id.

Bank Indonesia. 2003. Annual Report (several publications of 1995/96).

Bank Indonesia. 2003. Asset Price Index for Indonesia. Jakarta, Indonesia: Directorate of Economic Research and Monetary Policy.

Bank Indonesia. 2003. Indonesian Financial Statistics (several publications January 1995-December 2003).

Bank Indonesia. 2003. Financial Stability Review 2 (December).

Bank Indonesia.2004. Indonesian Banking Architecture. (January). Available on the BI website www.bi.go.id.

Beckhart, B. H. 1940. Monetary policy and commercial bank portfolios. The American Economic Review 30 (1).

Bernanke, B. S., and A. S. Blinder. 1988. Credit, money, and aggregate demand. The American Economic Review 78 (2).

Bernanke, B. S., and M. Gertler. 1999. Monetary policy and asset volatility. FRB of Kansas City Economic Review $4^{\text {th }}$ Quarter (84) (4).

Blinder, A. S. 1987. Credit rationing and effective supply failures. The Economic Journal 97 (386). 
Goeltom-Balance Sheet Vulnerability and Macroeconomic Management in Indonesia

Brunner, K., and A. H. Meltzer. 1988. Money and credit in the monetary transmission process. The American Economic Review 78 (2).

Central Statistics Board. 1992. Indonesia Flow of Fund, 1997-2002. Collaboration among Central Statistics Board, Bank Indonesia, and Ministry of Finance Republic of Indonesia.

CIRCLE-Indonesia. 2002. Labor Market Conditions in Indonesia (October). Jakarta, Indonesia.

Cukierman, A. 1992. Strategy, Credibility and Independence: Theory and Evidence. Cambridge, Massacussetts.

Gertler, M. 1988. Financial structure and aggregate economic activity: An overview. Journal of Money Credit and Banking 20 (3) (2).

Goeltom, S. M., and J. Agung. 2000. Financial liberalization, financial structure and investment in Indonesia. Bank Indonesia Occasional Paper.

Kuncoro, A. 2004. Fiscal deficits in Indonesia. In Fiscal Deficits in the Pacific Region. Edited by Akira Kohsaka. Routledge: T-F Group.

Lippi, F. 1999. Strategic monetary policy with non-atomistic wage setters. CEPR Discussion Paper No. 2218.

Mahi, R., and A. Jasmina. 2000. The impact of regional authonomy on the central government fiscal sustainability. Paper presented at the Indonesian Economic Recovery in Changing Environment Conference (September). Jakarta, Indonesia.

Silber, W. L. 1969. Monetary channel and the relative importance of money supply and bank portfolio. The Journal of Finance 24 (1).

Stiglitz, J. E., and B. Greenwald. 2003. Toward a NewParadigm in Monetary Economics. Cambridge University Press.

Warjiyo, P., and J. Agung (Editors). 2001. Transmission Mechanism of Monetary Policy in Indonesia. Directorate of Economic Research and Monetary Policy, Bank Indonesia. Jakarta, Indonesia. 
Gadjah Mada International Journal of Business, May-August 2005, Vol. 7, No. 2

\section{Appendix 1}

The Establishment of the Government Guarantee Scheme was introduced in January 1998 with the objective of regaining public confidence to the banking system. The blanket guarantee covers all third party liabilities of the banks. Members of the blanket guarantee program are banks incorporated in Indonesia. The guarantee has been a great burden to the government; nonetheless, removing it too early before the banking system had been put on a sound condition could jeopardize the gains it has benefited. Clear evidence that banks are progressing towards achieving a sustainable and prudent level of capital and are not sliding backwards towards insolvency should be warranted before lifting the scheme. Given this fact, the government has determined that the current blanket guarantee should be ended by 2004. On that account, the government shall institute a formal deposit protection scheme by establishing a Deposit Insurance Agency.

The Establishment of IBRA was conducted on January 6, 1998 under Presidential Decree. The main tasks of IBRA are as follows: (i) To nurse the unhealthy banks transferred from Bank Indonesia, (ii) To settle assets and liabilities of closed banks through an Asset Management Unit (iii) To restructure companies, (iv) To sell assets of closed banks and to settle the guarantee funds from the Government.

The Recapitalization of Banks is aimed at preserving the viability of banks having prospect to operate under a sound and healthy banking practice. The program started from the accomplishment of due diligence conducted by Bank Indonesia together with International Auditors for 198 banks (excluding 10 branch offices of foreign banks). To this point, the government has recapitalized 36 banks, comprising 7 private national banks, 4 Taken-Over Banks in 1998, 9 Taken-Over Banks in 1999, 12 Regional Development Banks, and 4 State-Owned Banks. In the course of the recapitalization program, the Government has issued bonds reaching IDR 433.21 trillion in nominal (around USD 50 billion in 1999), encompassing floating and fixed rate bonds, as well as hedge bonds, which stood at IDR 219.48 trillion, IDR 174.7 trillion, and IDR 39.03 trillion respectively. 
Goeltom-Balance Sheet Vulnerability and Macroeconomic Management in Indonesia

Appendix 2. Socio-Politic and Economic Events of 1997 - 2003

\begin{tabular}{|c|c|c|}
\hline Period & Socio-Politic & Economy \\
\hline \multicolumn{3}{|l|}{1997} \\
\hline July & & $\begin{array}{l}\text { Beginning of the financial crisis in Indonesia } \\
\text { Bank Indonesia (BI) widens the band of exchange rate } \\
\text { intervention }\end{array}$ \\
\hline August & & $\begin{array}{l}\text { The Government implements a fully flexible exchange } \\
\text { rate system }\end{array}$ \\
\hline September & & $\begin{array}{l}\text { BI reintroduces Money Market Securities and reduces } \\
\text { Reserve Requirement on non-rupiah }\end{array}$ \\
\hline November & & $\begin{array}{l}\text { The government adopts the IMF Stabilization Program } \\
\text { Liquidation of } 16 \text { insolvent commercial banks }\end{array}$ \\
\hline \multicolumn{3}{|l|}{1998} \\
\hline January & Political and security situation worsens & $\begin{array}{l}\text { Moody's and S\&P } 500 \text { reduced Indonesia's rating to } \\
\text { "non-investment rating" } \\
\text { Thegovernmentestablished IndonesiaBanking Restruc- } \\
\text { turing Agency (IBRA), followed by } \\
\text { the introduction of the Blanket Guarantee Program } \\
\text { The issue of Currency Board Arrangement is raised }\end{array}$ \\
\hline May & $\begin{array}{l}\text { Social riot of } 12 \text { May } \\
\text { Resignation of Soeharto as Indonesia's } \\
\text { President, replaced by B.J. Habibie }\end{array}$ & \\
\hline July & & Announcement of CGI commitment \\
\hline August & & Liquidation of 3 insolvent commercial banks \\
\hline September & & Debtrestructurization \\
\hline \multicolumn{3}{|l|}{1999} \\
\hline May & & $\begin{array}{l}\text { Establishment of the Act No.23/1999 regarding } \\
\text { Bank Indonesia }\end{array}$ \\
\hline August & $\begin{array}{l}\text { Abdul R. Wahid is assigned as the } 4^{\text {th }} \\
\text { Indonesia President }\end{array}$ & \\
\hline \multicolumn{3}{|l|}{2000} \\
\hline January & $\begin{array}{l}\text { Cabinet Reshuffle issues } \\
\text { Riots at Maluku and Mataram }\end{array}$ & \\
\hline February & $\begin{array}{l}\text { Resignation of General Wiranto from } \\
\text { the Cabinet }\end{array}$ & Acceptance of IMF loan (liquid) \\
\hline May & $\begin{array}{l}\text { Jakarta (Glodok) riot } \\
\text { Demonstration and riot in front of } \\
\text { Presidential palace }\end{array}$ & \\
\hline July & Conflict between Parliament and President & \\
\hline
\end{tabular}


Gadjah Mada International Journal of Business, May-August 2005, Vol. 7, No. 2

Continued from Appendix 2

(Socio-Politic and Economic Events of 1997 - 2003)

\begin{tabular}{|c|c|c|}
\hline Period & Socio-Politic & Economy \\
\hline $\begin{array}{l}2001 \\
\text { January }\end{array}$ & $\begin{array}{l}\text { Political situation accelerates due to the } \\
\text { Memorandum II to A.R. Wahid }\end{array}$ & \\
\hline March & Riots at Sampit and Ambon & $\begin{array}{l}\text { The relationship between Government and IMF } \\
\text { worsens. } \\
\text { Deterioration of Indonesia's rating outlook } \\
\text { (Moody's and S\&P) }\end{array}$ \\
\hline April & & Suspension of IMF loan acceptance \\
\hline June & $\begin{array}{l}\text { Pressures to conduct Special Assembly } \\
\text { of the General People Council }\end{array}$ & \\
\hline July & $\begin{array}{l}\text { Public rejection to the President's proposal } \\
\text { to dismiss Parliament } \\
\text { Special Assembly of the General People } \\
\text { Council } \\
\text { Resignation of A.R. Wahid as Indonesia's } \\
\text { President, replaced by Megawati Soekarnoputri }\end{array}$ & Improvement of Indonesia's rating outlook (S\&P) \\
\hline August & External supports for the new Government & \\
\hline September & World Trade Center Tragedy & \\
\hline October & $\begin{array}{l}\text { Increasing social tension and anti- } \\
\text { Americansentiments }\end{array}$ & \\
\hline November & & $\begin{array}{l}\text { Deterioration of Indonesia's rating and outlook (S\&P) } \\
\text { Extension of CGI commitment for } 2002\end{array}$ \\
\hline December & & IBRA assets sold to foreign investors \\
\hline $\begin{array}{l}2002 \\
\text { January }\end{array}$ & & IMF approves the loan acceptance (USD341 millions) \\
\hline March & & $\begin{array}{l}\text { Disinvestment of a commercial bank (BCA) } \\
\text { Trend Bullish of Asia currencies }\end{array}$ \\
\hline April & & $\begin{array}{l}\text { Paris Club III rescheduling } \\
\text { Deterioration of Indonesia's credit rating (S\&P) }\end{array}$ \\
\hline May & & Strengthening of Asian currencies \\
\hline June & & $\begin{array}{l}\text { London Club rescheduling } \\
\text { IMF approves the loan acceptance(USD358 millions) }\end{array}$ \\
\hline August & $\begin{array}{l}\text { Annual Assembly of the General People } \\
\text { Council }\end{array}$ & $\begin{array}{l}\text { Sing Tel Singapore buys Telkomsel's shares } \\
\text { Weakening of the Yen } \\
\text { FITCH raises Indonesia's credit rating }\end{array}$ \\
\hline
\end{tabular}


Goeltom-Balance Sheet Vulnerability and Macroeconomic Management in Indonesia

Continued from Appendix 2

(Socio-Politic and Economic Events of 1997 - 2003)

\begin{tabular}{|c|c|c|}
\hline Period & Socio-Politic & Economy \\
\hline September & & S\&P raises Indonesia's credit rating \\
\hline October & Bali Tragedy (bombing) & \\
\hline November & & $\begin{array}{l}\text { Fed Fund Rate decreases } \\
\text { Disinvestment of } 51 \% \text { Bank Niaga's shares }\end{array}$ \\
\hline December & $\begin{array}{l}\text { Arrangement between the Indonesian } \\
\text { government and Aceh Liberalization } \\
\text { Movement(GAM) }\end{array}$ & $\begin{array}{l}\text { Loan acceptance from IMF } \\
\text { Disinvestment of } 41,9 \% \text { Indosat's shares }\end{array}$ \\
\hline $\begin{array}{l}2003 \\
\text { January }\end{array}$ & Public demonstration to reject price increases & $\begin{array}{l}\text { CGI Meeting approves a new commitment } \\
\text { Deal between Indonesia and the IMF regarding } \\
\text { the economic reform program }\end{array}$ \\
\hline March & America attacks Iraq & \\
\hline August & JW Marriot Hotel Tragedy (bombing) & \\
\hline
\end{tabular}

